\title{
A MARKET TEST FOR BAYH-DOLE PATENTS
}

\author{
Ian Ayres $\dagger$ \& Lisa Larrimore Ouellette $\ddagger$
}

The Bayh-Dole Act, which allows patenting of federally funded research, has been praised for driving growth but also criticized for creating unnecessary deadweight loss and contributing to a patent "anticommons." Much of the controversy stems from Bayh-Dole's differing effects on different inventions. The dominant justification for Bayh-Dole patents is commercialization theory: the idea that exclusive rights are necessary to bring inventions to market. This theory is convincing for inventions like pharmaceuticals with high regulatory barriers and low imitation costs, but not when exclusivity is unnecessary for commercialization, such as for Stanford's widely licensed patents on early recombinant DNA technology. The problem is that for many government-funded inventions it is difficult to determine whether exclusive patent grants are necessary to incentivize commercialization.

To solve this difficulty, we propose a "market test" for federally funded inventions at universities and other nonprofits. Before charging significant licensing fees for these inventions, these federal grant recipients would first be required to find out whether firms would be willing to commercialize the invention in exchange for a nonexclusive license with a nominal fee. If a company is willing to commit to developing the invention under a nonexclusive license, then an exclusive license-or a nonexclusive license with high fees-would be contrary to the public interest. More generally, using a formal economic model, we show that deadweight loss can be reduced through an auction that forces bidders to reveal the least amount of exclusivity needed to induce commercialization, that revenue cap bidding is more efficient than duration bidding, and that defensive bidding by firms that consume as well as produce the invention will not increase deadweight

$\dagger$ William K. Townsend Professor of Law, Yale Law School.

$\ddagger$ Assistant Professor of Law, Stanford Law School.

For helpful comments, we thank Ryan Abbott, Michael Abramowicz, Tun-Jen Chiang, Colleen Chien, Jorge Contreras, Dick Craswell, Jeanne Fromer, Daniel Hemel, Camilla Hrdy, Daniel Ho, Tai-Jan Huang, Peter Lee, Mark Lemley, Jonathan Masur, Doug Melamed, Nicholson Price, Arti Rai, Michael Risch, Ted Sichelman, and participants at the Notre Dame Junior Patent Roundtable, the 2016 Works-in-Progress Intellectual Property Conference, the 26th Annual Meeting of the American Law and Economics Association, and the 16th IP Scholars Conference. 
loss. We discuss how the market test requirement could be structured and how due diligence milestones and other provisions could be used to discourage gaming.

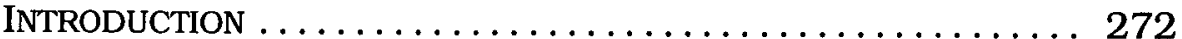

I. THE PROBLEM: WHICH FEDERALLY FUNDED INVENTIONS SHOUld Be PATENTEd AND EXClusively LiCENSED? . . 280

A. Economic Justifications for Patents in the University Context.................. 281

1. Ex Ante Innovation Incentives ........... 283

2. Ex Post Commercialization .............. 286

3. Disclosure, Transactions, and Signals ..... 290

4. Revenue for University Research ......... 291

5. International Considerations ............. 294

6. Copyleft-Style Patent Licensing ......... 296

B. When Is an Exclusive Right Necessary for

Commercialization? .................. 298

II. THE SOlUtion: A MARKET TEST OF EXClUSIVITY FOR BAYH-Dole Patents .................... 301

A. Basic Structure of the Market Test........ 302

B. Modeling Bayh-Dole Patent Exclusivity Auctions ........................... 304

1. Limiting the Deadweight Loss of Incentivizing Commercialization .......... 305

2. Competing over Duration or Revenue Caps . 308

3. Defensive Bidding by Consumers ........ 311

III. IMPLEMENTING THE MARKET TEST . . . . . . . . . . 316

A. Institutional Actors ..................... 317

1. Universities . ..................... 317

2. Grant Agencies.................... 320

3. Congress ..................... 323

B. Timing, Enforcement, and Gaming ......... 324 ConClusion ............................... 330

\section{INTRODUCTION}

The federal government provides over $\$ 100$ billion in direct support for scientific research each year-including $47 \%$ of all basic research funding and $37 \%$ of all applied research funding in the United States-most of which goes to universities, other nonprofits, or federal research institutes. ${ }^{1}$ Recipients of this public funding have become increasingly active players in the

1 NAT’L SC. BD., NAT'L SCI. FOUND., SCIENCE \& ENGINEERING INDICATORS 2016, at 4-29 tbl.4-3, http://www.nsf.gov/statistics/2016/nsb20161/uploads/ / / nsb20161.pdf [https://perma.cc/X6JW-TXK7]. 
U.S. patent system since the Bayh-Dole Act of 1980, which clarified that they can patent and license federally funded research results to promote commercialization of inventions arising from these results. ${ }^{2}$ Today, every major U.S. research institution has a technology transfer office, and the growth in university patenting and licensing has been praised for "rejuvenating the entire U.S. economic system." ${ }^{3}$ A biotechnology lobbying report touts that Bayh-Dole licensees contributed as much as \$1 trillion in sales and up to three million U.S. jobs between 1996 and 2010.4 Inspired by this success, many other countries are emulating the U.S. system. ${ }^{5}$

But the Bayh-Dole Act and its export abroad have also been subject to a steady undercurrent of academic criticism, which has emphasized both harm to scientific norms and harm to the consumers who bear the costs of unnecessary patents. ${ }^{6}$ There is also increasing public concern about whether univer-

235 U.S.C. \$\$ 200-212 (2012). The lesser-known Stevenson-Wydler Act of 1980 similarly governs technology transfer by federal laboratories. 15 U.S.C. \$8 3701-3714 (2012). For the history of patents on publicly funded research and a critique of these laws, see Rebecca S. Eisenberg, Public Research and Private Development: Patents and Technology Transfer in Government-Sponsored Research, 82 VA. L. REV. 1663, 1671-95 (1996).

3 Vicki Loise \& Ashley J. Stevens, Commentary, The Bayh-Dole Act Turns 30, 2 SCI. TRANSLATIONAL MED. 1, 1 (2010). For simplicity, we use "university patenting" to refer to patenting by universities, nonprofits, or the government. For-profit firms also receive some direct federal research funding, and a modified version of our proposal might apply to them, but most of our discussion is specific to the nonprofit research context. Our proposal might also be compelling for nonBayh-Dole patenting by universities, but we think it is most compelling for inventions that were created with public funding.

4 BIOTECHNOLOGY INDUS. ORG., THE ECONOMIC CONTRIBUTION OF UNIVERSITY/NONPROFIT INVENTIONS IN THE UNITED STATES: 1996-2010, at 3 (2012), http://www.bio. org/articles/economic-contribution-universitynonprofit-inventions-unitedstates-1996-2010 [https://perma.cc/J4R3-ERBE] (adjusting monetary amounts for inflation to 2016 dollars); see also Innovation's Golden Goose, THE ECONOMIST, Dec. 14,2002 , at 3 (hailing Bayh-Dole as "[p]ossibly the most inspired piece of legislation to be enacted in America over the past half-century").

5 See Evita Paraskevopoulou, The AdOPTION OF BAYH-DOLE TYPE Policies in DEVELOPING COUNTRIES (2013), https://www.innovationpolicyplatform.org?/sites/ default/files/rdf_imported_documents/TheAdoptionOfBayhDoleTypePoliciesIn DevelopingCountries.pdf [https://perma.cc/CF5X-FBXQ]

6 For a summary of criticism in the domestic context, see Lisa Larrimore Ouellette, Comment, Addressing the Green Patent Global Deadlock Through Bayh-Dole Reform, 119 YALE L.J. 1727, 1730 \& nn.18-20 (2010) [hereinafter Ouellette, Addressing the Green Patent Global Deadlock]. For critiques of Bayh-Dole's global spread, see David C. Mowery \& Bhaven N. Sampat, The Bayh-Dole Act of 1980 and University-Industry Technology Transfer: A Model for Other OECD Governments?, in ESSAYS IN HONOR OF EDWIN MANSFIELD 233, 241 (Albert N. Link \& F.M. Scherer eds., 2005); and Anthony D. So et al., Is Bayh-Dole Good for Developing Countries? Lessons from the US Experience, 6 PLOS BIO. 2078 (2008). 
sity patent owners are really acting in the public interest. Universities have been criticized for selling their patents to patent assertion entities, also known as "patent trolls."7 Boston University was labeled a patent troll itself for its successful suit against tech giants such as Apple, Microsoft, Amazon, HP, and Samsung for infringing a patent on gallium nitride films, ${ }^{8}$ and this critique has been echoed against other university patent plaintiffs. ${ }^{9}$ University patent litigants have won staggering awards in district court, such as the Wisconsin Alumni Research Foundation's \$234 million award against Apple (appeal pending) ${ }^{10}$ and Carnegie Mellon University's $\$ 1.5$ billion award against Marvell Semiconductor (reduced to $\$ 750$ million in a settlement). ${ }^{11}$ One study found "a number of lawsuits in which university software patents have been used not for purposes of

7 See, e.g., Heidi Ledford, Universities Struggle To Make Patents Pay, 501 NATURE 471, 471 (2013) [hereinafter Ledford, Universities Struggle To Make Patents Payl (noting criticism of Caltech's sale of patents to a patent assertion entity).

8 See John Koetsier, Congratulations, Boston University, You're Now a Patent Troll, VentureBeat (July 3, 2013, 12:17 PM), http://venturebeat.com/2013/07/ 03/congratulations-boston-university-youre-now-a-patent-troll [https:// perma.cc/4B2K-4AWH]. Twenty-five of the companies agreed to undisclosed licensing fees. See Jon Brodkin, Patent-Waving Boston U. Wins Cash from Apple, Amazon, and Microsoft, ARS TECHNICA (Jan. 16, 2014, 12:45 PM), http://arstechnica.com/tech-policy/2014/01/patent-waving-boston-u-wins-cash-fromapple-amazon-and-microsoft [https://perma.cc/5NLU-AL37]. Boston University won over $\$ 13$ million from the remaining three defendants. See Joel Brown, $B U$ Wins $\$ 13$ Million in Patent Infringement Suit, BU TODAY (Dec. 7, 2015), http:// www.bu.edu/today/2015/bu-wins-13-million-in-patent-infringement-suit [https://perma.cc/7CUN-6K7M].

9 See, e.g., Joe Mullin, Public University, Public Research-And Four Big Patent Suits, ARS TECHNICA (Nov. 11, 2014, 9:45 AM), http://arstechnica.com/techpolicy/2014/11/public-university-public-research-and-four-big-patent-suits [https://perma.cc/BC9B-6LQC] (noting that the "increasing number of patent lawsuits" filed by U.S. universities "has spawned some criticism that universities are ... engag[ing] in litigation strategies similar to that of so-called patent trolls' "). Mark Lemley was one of the first to identify this sentiment that "universities are the new patent trolls," though he opined that "the general answer" is that they are not. Mark A. Lemley, Are Universities Patent Trolls?, 18 FORDHAM INTELL. PROP. MEDIA \& ENT. L.J. 61 1, 611,612 n.1 (2008) [hereinafter Lemley, Are Universities Patent Trolls?].

10 See Andrew Chung, Apple Ordered To Pay \$234 Million to University for Infringing Patent, REUTERS (Oct. 16, 2015, 6:58 PM), http://www.reuters.com/ article/us-apple-patent-defense-idUSKCNOSA20E20151016 [https://perma.cc/ RVT6-YKVQ].

11 See Susan Decker, Marvell Technology To Pay $\$ 750$ Million to Carnegie Mellon, 91 PAT. TRADEMARK \& COPYriGHT J. (BNA) 1126 (Feb. 19, 2016); Joe Mullin, Chipmaker Hopes To Overturn Largest Patent Verdict Ever: $\$ 1.5$ Billion, ARS TECHNICA (Apr. 10, 2015, 11:51 AM), http://arstechnica.com/tech-policy/2015/ 04/chipmaker-hopes-to-overturn-largest-patent-verdict-ever-1-5-billion [https:/ /perma.cc/A9ZY-BXXY]. 
fostering commercialization, but instead to extract rents in apparent holdup litigation." 12

When a university seeks to nonexclusively license its patents to firms that are already using the technology and sues unwilling firms for infringement, it is hard to see how Bayh-Dole is fulfilling its statutory goal of "promot[ing] the utilization of inventions arising from federally supported research or development." 13 The inventions at issue already were being used by firms who lack exclusive rights to those patents-otherwise there would have been nothing to sue over-indicating that such exclusivity was not required for commercialization. And the same logic applies when a university charges to license an invention nonexclusively, such as for the acclaimed Cohen-Boyer patents on early recombinant DNA technology that brought in $\$ 255$ million in licensing fees for Stanford. ${ }^{14}$ The Cohen-Boyer patents are not an anomaly. ${ }^{15}$ University technology transfer offices grant more nonexclusive licenses than exclusive ones, ${ }^{16}$ and some commentators have argued for even wider use of nonexclusive licensing. ${ }^{17}$ We think, to the con-

12 Arti K. Ral, John R. Allison, \& Bhaven N. Sampat, University Software Ownership and Litigation: A First Examination, 87 N.C. L. REV. 1519, 1519 (2009).

$13 \quad 35$ U.S.C. $\$ 200$ (2012).

14 See Kirsten Leute, Patenting and Licensing of University-Based Genetic Inventions-A View from Experience at Stanford University's Office of Technology Licensing, 8 COMMUNITY GENETICS 217, 221 (2005). As Rebecca Eisenberg has explained, "[I]t can hardly be argued that the[se] patents have done anything to promote product development that would not have occurred if the patented technology had instead been placed in the public domain." Eisenberg, supra note 2, at 1710 .

15 See, e.g., David C. Mowery et al., The Growth of Patenting and Licensing by U.S. Universities: An Assessment of the Effects of the Bayh-Dole Act of 1980, 30 RES. POL'Y 99, 118 (2001) (concluding that "[i]n the[ ] three universities [studied], biotechnology research tools have been licensed widely," but noting that "this practice does not spur technology transfer" and instead simply provides a new source of revenue for the university).

16 The percentage of nonexclusive licenses out of the thousands of licenses reported each year on an annual survey of technology transfer offices was 60 to $65 \%$ from 2009 through 2013. Statistics Access for Technology Transfer (STATT) Database, ASS'N OF UNIV. TECH. MANAGERS, http://www.autm.net/resourcessurveys/research-reports-databases/statt-database-(1) [https://perma.cc/ 4CXC-VG7F] (proprietary database). The database does not disclose the amount of income received from the two types of licenses.

17 See, e.g., Bryan Collinsworth \& Sara E. Crager, Should Academic Therapeutic Patents Go to the Highest Bidder?, 24 EXPERT OPINION ON THERAPEUTIC PATENTS 481,483 (2014) (“'M]any university innovations have been successfully licensed on a nonexclusive basis, and we advocate incentivizing such licensing as the 'default' approach . . . ."); Martin Kenney \& Donald Patton, Reconsidering the Bayh-Dole Act and the Current University Invention Ownership Model, 38 RES. POL'Y 1407, 1414, 1417-18 (2009) (proposing a mandatory nonexclusive licensing model for university patent ownership); Lemley, Are Universities Patent Trolls?. supra note 9 , at 626 (noting that, at times, a nonexclusive license will maximize 
trary, that if the conventional wisdom is correct that Bayh-Dole patents are justified only by their commercialization incentive, ${ }^{18}$ then a nonexclusive license is prima facie evidence that the invention ought not to have been patented at all. ${ }^{19}$

The genius of Bayh-Dole, in the words of The Economist, is that it gives firms the exclusive rights needed "to invest millions more of their own money to turn a raw research idea into a marketable product" rather than leaving university inventions "in warehouses gathering dust." 20 There is no question that university technology transfer can create enormous value and that the Bayh-Dole system is an improvement on the prior system of uncertain patent rights in government hands. ${ }^{21}$ The success of Silicon Valley can be attributed in part to Stanford's encouragement of faculty or students who wanted to commercialize inventions created with university resources; companies spawned include Hewlett-Packard, Cisco, Yahoo!, Sun Microsystems, and Google (for which Larry Page's web-crawling efforts at one point used almost half of Stanford's internet bandwidth). ${ }^{22}$ In some cases, exclusivity is needed to incentivize entrepreneurs and inventors to take a risk on a new idea that would otherwise gather dust. (This may have been the case for Google's foundational patents, which established companies such as Yahoo!, Excite, and AltaVista were uninterested in licensing. ${ }^{23}$ ) But this commercialization rationale for exclusive patents on publicly funded inventions makes little sense

an invention's impact on society); Carolyn L. Treasure et al., What Is the Public's Right To Access Medical Discoveries Based on Federally Funded Research?, 311 JAMA 907, 908 (2014) (arguing that "[i]f universities issued more nonexclusive licenses" it would increase access to health technologies and that "legislative strategies may be needed to incentivize nonexclusive licensing").

18 See infra Part I.

19 A caveat to this is that if the nonexclusive license is only offered to a small number of firms or otherwise has an appreciable effect on quantity, then it may have similar benefits (and costs) as an exclusive license.

20 Innovation's Golden Goose, supra note 4.

21 For a thorough history of university patenting, including discussion of the Institutional Patent Agreements that allowed universities to take title to patents even before the Bayh-Dole Act, see generally Peter Lee, Patents and the University, 63 DUKE L.J. 1 (2013) [hereinafter Lee, Patents and the University].

22 See WALTER ISAACSON, THE INNOVATORS 450, 457 (2014); see also MARIANA Mazzucato, The Entrepreneurial State: Debunking Public vs. Private Sector MYTHS (2015) (discussing the key role of federal funds in the development of numerous breakthrough technologies).

23 See ISAACSON, supra note 22 , at 462. 
when numerous firms are already eager to use the inventions without exclusivity. ${ }^{24}$

Federal agencies do have legal tools to prevent abuse of university patents. The Bayh-Dole Act allows agencies to exercise "march-in rights" to compel licensing of university patents if necessary to make the invention "available to the public on reasonable terms" or "to alleviate health or safety needs," 25 and "in exceptional circumstances" an agency may determine "that restriction or elimination of the [patent] right . . . will better promote the policy and objectives of" the Act. ${ }^{26}$ These rights have never been exercised. ${ }^{27}$ But given recent concern about the high price of pharmaceuticals and the substantial role universities play in basic drug discovery - one study found that about a quarter of new drugs approved from 1998 to 2007 originated in universities ${ }^{28}$ - over fifty members of the House of Representatives recently (albeit unsuccessfully) urged the $\mathrm{Na}-$ tional Institutes of Health (NIH) to exercise their march-in rights. ${ }^{29}$

The problem with more frequent exercise of march-in rights, however, is that exclusive patent rights often are necessary to drive commercialization, particularly in the biomedical context. Pharmaceutical companies will not undertake the significant expense of clinical trials if they do not have sufficient

24 We are not the first to make this observation. See, e.g., Eisenberg, supra note 2, at 1710; Arti Kaur Rai, Regulating Scientific Research: Intellectual Property Rights and the Norms of Science, 94 Nw. U. L. REv. 77, 120, 135 (1999).

2535 U.S.C. $\$ \S 201(\mathrm{f}), 203(\mathrm{a})(1)-(2)(2012)$.

2635 U.S.C. $\$ 202$ (a)(ii). Furthermore, the government retains a paid-up, nonexclusive license to practice inventions covered by the Act. 35 U.S.C. $\S 202(\mathrm{c})(4)$.

27 See Ryan Whalen, Note, The Bayh-Dole Act \& Public Rights in Federally Funded Inventions: Will the Agencies Ever Go Marching in?, 109 Nw. U. L. REV. 1083, 1083 (2015).

28 Robert Kneller, The Importance of New Companies for Drug Discovery: Origins of a Decade of New Drugs, 9 NATURE Reviews DRUG Discovery 867, 869 (2010).

29 Letter from Lloyd Doggett, U.S. Rep., et al. to Sylvia Mathews Burwell, Sec'y, U.S. Dep't of Health \& Human Servs., \& Francis S. Collins, Dir., Nat'l Insts. of Health (Jan. 11, 2016), http://keionline.org/sites/default/files/Doggett-51 member-MarchIn-1 1Jan2016.pdf [https://perma.cc/J4EF-RZ4Y]; see John M. Clerici \& Phillip Bradley, Federal Gov't Won't March in When It Comes to Drug Prices, LAW 360 (July 11, 2016, 4:36 PM), http://www.law360.com/articles/ 815909/federal-gov-t-won-t-march-in-when-it-comes-to-drug-prices [https:// perma.cc/N3EV-LDG5]. Another option would be to use 28 U.S.C. \$ 1498, which allows government use of any U.S. patent in exchange for reasonable compensation. See Hannah Brennan et al., A Prescription for Excessive Drug Pricing: Leveraging Government Patent Use for Health, 18 YALE J.L. \& TECH. 275, 319-21 (2016). 
patent rights on the compound of interest, ${ }^{30}$ and the need for a lengthy exclusivity period skews medical research toward diseases for which clinical trials can be conducted more quickly. ${ }^{31}$ (Of course, patents are only one of many policy tools to correct market failures at different stages of the R\&D process-to the extent firms have insufficient incentives for commercialization, governments can and do use commercialization grants, tax incentives, or prizes, and these alternative tools often might be superior. ${ }^{32}$ But here we focus on improving rather than replacing Bayh-Dole.)

So when are exclusive patent rights actually necessary to induce commercialization? A technology for which the answer to this question is nonobvious is the gene-editing technique known as CRISPR, which has been called "the biggest biotechnology advance since the polymerase chain reaction" (a DNAcopying technique developed in 1983). ${ }^{33}$ The CRISPR technology is currently subject to what Professor Jacob Sherkow calls "an absolutely humungous biotech patent dispute" over who gets priority: a group at the University of California at Berkeley, or a different group at the Broad Institute of Harvard and MIT. ${ }^{34}$ Berkeley and the Broad Institute have granted different startups exclusive rights to their CRISPR patents for therapeutic purposes, so the priority battle may determine which star-

30 See Benjamin N. Roin, Unpatentable Drugs and the Standards of Patentability, 87 TEX. L. REV. 503, 545-47 (2009). For a summary of the economics of drug development and the importance of patents in the pharmaceutical industry, see Lisa Larrimore Ouellette, How Many Patents Does It Take To Make a Drug? Follow-on Pharmaceutical Patents and University Licensing, $17 \mathrm{MICH}$. TELECOMM. \& TECH. L. REV. 299, 302-03 (2010) [hereinafter Ouellette, How Many Patents Does It Take To Make a Drug?].

31 See Eric Budish, Benjamin N. Roin, \& Heidi Williams, Do Firms Underinvest in Long-Term Research? Evidence from Cancer Clinical Trials, 105 AM. ECON. REV. 2044, 2045-50 (2015). Patents used to be less important to university-industry collaborations, but demand for exclusive licenses to NIH-sponsored inventions grew in the 1960 s in response to regulatory changes that increased the cost of bringing new drugs to market. See Roberto Mazzoleni, Before Bayh-Dole: Public Research Funding, Patents, and Pharmaceutical Innovation (1945-1965), 20 INDUS. \& CORP. CHANGE 721, 724 (2011).

32 See Daniel J. Hemel \& Lisa Larrimore Ouellette, Beyond the Patents-Prizes Debate, 92 TEX. L. REV. 303, 314 (2013) [hereinafter Hemel \& Ouellette, Beyond the Patent-Prizes Debate] (comparing these mechanisms); see also Camilla A. Hrdy, Commercialization Awards, 2015 WIS. L. REV. 13, 51-72 (reviewing government incentives for commercialization outside the patent system, particularly at the state and local level).

33 Heidi Ledford, Bitter Fight over CRISPR Patent Heats Up, 529 NATURE 265, 265 (2016).

34 Id. (quoting Professor Jacob Sherkow, New York Law School). 
tup survives. ${ }^{35}$ But is exclusivity really necessary for the development of gene-editing therapeutics, or would it better serve the public interest to have multiple firms entering this space, without the constraint of a patent on the fundamental technique? Is there some way to tell whether CRISPR is more like the small-molecule pharmaceuticals for which exclusive rights clearly are needed or more like Boston University's gallium nitride films and Stanford's basic recombinant DNA techniques, for which patents seem to merely create unnecessary deadweight loss? ${ }^{36}$

In this Article, we argue that the answer is "yes." In particular, we propose a "market test" for federally funded inventions at universities and other nonprofits. ${ }^{37}$ In short, before exclusively licensing these inventions for the full remaining patent term, federal grant recipients would be required to offer the invention under a nonexclusive license for a nominal fee to cover the costs of patent acquisition. ${ }^{38}$ If a company will develop the invention under a nonexclusive license, then the uni-

35 See Jenny Rood, Who Owns CRISPR?, THESCIENTIST (Apr. 3, 2015), http:// www.the-scientist.com/?articles.view/articleNo/42595/title/Who-OwnsCRISPR- [https://perma.cc/JU9M-F6HL].

36 Mark Lemley has argued that the pharmaceutical and biotechnology industries are a special case "because of the regulatory barriers to entry" that make it very expensive to bring a product to market and comparatively cheap to imitate it, and that "[i]n the IT industries, and even in industries like medical devices, there is no reason to believe that exclusive rights are necessary to encourage commercialization." Lemley, Are Universities Patent Trolls?, supra note 9, at 624 . For a summary of why patents are less likely to be necessary for commercialization in engineering fields (and might in fact hinder the spread of these technologies), see Ouellette, Addressing the Green Patent Global Deadlock, supra note 6, at 1731-32. But we think there is no strong reason to believe that exclusive rights are not necessary to encourage commercialization for at least some inventions in these fields. For a review of the ambiguous evidence on the extent to which patents are needed for different purposes, see Lisa Larrimore Ouellette, Patent Experimentalism, 101 VA. L. REV. 65, 75-87 (2015) [hereinafter Ouellette, Patent Experimentalism].

37 We focus on federally funded inventions at universities because this seems like the clearest test ground for our proposal, both analytically and politically. If our market test is successful in this context, it is worth considering whether it should be applied to university patenting more broadly (for example, inventions that are funded by state grants, foundations, or even for-profit firms) and whether it should be applied to federally funded inventions more broadly (including grants received by private, for-profit firms). Our market test could also be applied in other contexts in which commercialization is the main reason for granting patents. Not all of our discussion below applies with equal force to all of these contexts.

38 To reduce administrative costs, the optimal approach may be to allow this mechanism to be triggered by an interested licensee. See infra notes 145, 214 and accompanying text. Our proposal would thus only affect patents that numerous firms are eager to license-which may be a small fraction of all university patents, but which likely contribute disproportionately to social cost. 
versity should be required to offer free nonexclusive licenses to anyone else who wants to practice the invention. Market evidence that a firm is willing to commercialize the invention without the benefit of being able to constrain quantity should preclude grant recipients from using an exclusive license-or any nonexclusive license that leads to quantity constraints. ${ }^{39}$

Our argument proceeds in three parts. In Part I, we explain why commercialization theory is currently the dominant justification for Bayh-Dole patents, and we set out the challenge of determining whether exclusive patent grants are necessary to incentivize commercialization. Part II describes our market test in more detail. We show that deadweight loss can be reduced through an auction that forces bidders to reveal the least amount of exclusivity needed to induce commercialization, that revenue cap bidding is more efficient than duration bidding (though perhaps less administratively feasible), and that defensive bidding by firms that consume as well as produce the invention will not increase deadweight loss. Finally, Part III explores how different actors-universities, grant agencies, and Congress-might help implement this market test of exclusivity for Bayh-Dole patents, and how due diligence milestones and other provisions can be used to discourage gaming. By showing that it would not be infeasible to limit Bayh-Dole patents to those areas in which they are actually needed for commercialization, we hope to shift the burden to Bayh-Dole defenders to develop stronger theoretical and empirical accounts of why patents should be allowed in other cases.

The Problem: Which Federally Funded InVentions Should Be PATENTED AND EXCLUSIVELY LICENSED?

In the Introduction, we claimed that under the conventional account of the Bayh-Dole Act, universities are not acting in the public interest when they bring patent lawsuits against firms who have commercialized the technologies without owning the exclusive rights, or even when they broadly license their technologies under nonexclusive licenses. In subpart I.A, we describe how this claim follows from the commercialization

39 As we discuss in Part I, there are other potential justifications for a quantity-constraining license besides commercialization theory, although these have not been emphasized as much in the Bayh-Dole debates. We are agnostic on whether any of these benefits might outweigh the costs of exclusivity, but we note that justifying exclusive Bayh-Dole patents on these grounds would require a substantial reworking of Bayh-Dole theory and practice. 
theory of Bayh-Dole, and we discuss the other theories that might be developed further to justify Bayh-Dole patents that are unnecessary for commercialization. Subpart I.B then turns to the problem of identifying when exclusive patent rights are unnecessary for commercialization and thus harmful to the public interest under the standard account.

\section{A. Economic Justifications for Patents in the University Context}

Patents have significant social costs. Most obviously, patents create deadweight loss because they are effective only to the extent they give patentees some market power that allows prices to be raised above marginal cost. ${ }^{40}$ (Because patents effectively function as a concentrated sales tax on patented goods, this deadweight loss is generally higher than the deadweight loss of providing a similar incentive through broadbased taxation. ${ }^{41}$ ) Patents also can impede cumulative innovation, ${ }^{42}$ and they create substantial administrative and enforcement costs. ${ }^{43}$ In the university context, while patents do not directly impede subsequent academic research (because academics tend to ignore patents and are rarely sued for infringement), ${ }^{44}$ patents do appear to impede access to physical

40 See N. Gregory Mankiw ET AL., PRinciples of Economics 310-13 (7th ed., 2014) (introducing these concepts); Mark A. Lemley, Property, Intellectual Property, and Free Riding, 83 TEx. L. REV. 1031, 1059 [hereinafter Lemley, Free Riding] ("By definition, therefore, the intellectual property system permits owners to raise price above marginal cost, creating deadweight losses by raising the price to consumers.").

41 See Hemel \& Ouellette, Beyond the Patents-Prizes Debate, supra note 32 , at 314-15 (describing the patent "shadow tax" and explaining why the deadweight loss of monopoly is generally greater than the deadweight loss of income taxation).

42 Measuring the extent to which patents in fact impede cumulative innovation in different contexts is challenging, but for a clever empirical study that concludes that "on average gene patents have had no effect on follow-on innovation." Bhaven Sampat \& Heidi L. Williams, How Do Patents Affect Follow-on Innovation? Evidence from the Human Genome 1 (Oct. 13, 2015) (unpublished manuscript), http://economics.mit.edu/files/10782 [https://perma.cc/8GT3H345].

43 See Lemley, Free Riding, supra note 40, at 1059-64 (describing these and other costs); see also Hemel \& Ouellette, Beyond the Patent-Prizes Debate, supra note 32, at 364-65 (roughly estimating the administrative costs of the patent system at $\$ 10$ billion per year, most of which is paid by private parties).

44 See Lisa Larrimore Ouellette, Note, Access to Bio-Knowledge: From Gene Patents to Biomedical Materials, 2010 STAN. TECH. L. REV. N1 9141 (2010) [hereinafter Ouellette, Access to Bio-Knowledge] (noting that scientists "typically ignore patents and are rarely sued"). 
materials such as cell lines, ${ }^{45}$ and they may have other negative effects on the practice and norms of science. ${ }^{46}$

From a social welfare perspective, patents thus should be granted only when they produce some benefit that outweighs these costs. Here, we first explain why the traditional justification for patents-that they provide ex ante incentives to invent-has so far been considered less persuasive in the university context. We then turn to what has been widely recognized as the more compelling argument for patents on federally funded inventions: that the patents provide ex post incentives to commercialize. ${ }^{47}$

Finally, we note four other benefits that university patents might bring: increased disclosure and signaling about the underlying inventions; increased revenue for the university; the ability to internalize foreign benefits from U.S. spending on grants; and the ability to use copyleft-style patent licenses to prevent unnecessary constraints on certain technologies. In some cases, a combination of all the benefits we discuss may outweigh the costs of exclusivity, even where exclusivity is unnecessary for commercialization. But these alternative benefits are not why the Bayh-Dole Act was enacted and have not been the foundation of the policy debates surrounding Bayh-Dole. If exclusive patent rights are to be justified on these grounds, it would require a rethinking of both Bayh-Dole theory and practice. ${ }^{48}$

45 See generally id. (citing numerous empirical studies, primarily based on survey results).

46 See Jeremy M. Grushcow, Measuring Secrecy: A Cost of the Patent System Revealed, 33 J. LEGAL STUD. 59, 75-79 (2004); Wei Hong \& John P. Walsh, For Money or Glory? Commercialization. Competition, and Secrecy in the Entrepreneurial University, 50 Soc. 8. 145, 147-49 (2009); Rai, supra note 24, at $85-86$.

47 See Eisenberg, supra note 2, at 1668-69; Lemley, Are Universities Patent Trolls?, supra note 9, at 621; Rai, supra note 24, at 97-99; see also NAT"L RES. COUNCIL Nat'L ACADS., MaNaging University INTEllectual PROPERTY IN THE PUBliC INTEREST 60 (2011) ("The first goal of university technology transfer involving IP is the expeditious and wide dissemination of university-generated technology for the public good.").

48 One of us is separately considering a number of these underappreciated benefits of Bayh-Dole. See generally Daniel J. Hemel \& Lisa Larrimore Ouellette. Bayh-Dole Beyond Borders (unpublished manuscript) (Sept. 1, 2016) (on file with authors) [hereinafter Hemel \& Ouellette, Bayh-Dole Beyond Borders]; Daniel J. Hemel \& Lisa Larrimore Ouellette, Innovation Policy Pluralism (Aug. 7, 2016) (unpublished manuscript) (on file with authors) [hereinafter Hemel \& Ouellette, Innovation Policy Pluralism]. 


\section{Ex Ante Innovation Incentives}

The traditional justification for patent laws is that they provide ex ante incentive to innovate by allowing ex post recovery of research costs (including associated risks). ${ }^{49}$ But as Rebecca Eisenberg writes, this argument "loses much of its force in the case of inventions made with public funding" where taxpayers have already "absorbed the risk that nothing would come of [their] investment." 50 Federal grants typically cover the fixed costs of a given research project and the public bears the risk of failure, so there is no obvious need to allow grant recipients to charge supra-competitive prices to recoup their costs. ${ }^{51}$ Bayh-Dole scholars have noted that grant recipients already have strong incentives to innovate, including the desire for tenure and promotion, awards, and prestige. ${ }^{52}$ Perhaps even more directly, grant recipients receive money to pursue particular projects and must report on their results, ${ }^{53}$ and they are unlikely to receive additional grants if they do not successfully follow through with earlier projects. Grants are critical for supporting graduate students and postdoctoral associates, for purchasing laboratory equipment, and often for funding part of the principle investigator's salary-a more immediate financial concern than speculative patent royalties. Unlike scientists at private firms, university scientists generally must raise all of the capital necessary to support their research before spending it; there is not currently a market for loans to academic scientists that might be paid back through patent royalties. ${ }^{54}$

49 See, e.g., STAFF OF Subcomm. ON PATENTS, TRAdemarks \& COPYRIGHTS OF THE S. COMM. ON THE JUDICIARY, 85TH CONG., AN ECONOMIC REVIEW OF THE PATENT SYSTEM, STUdY No. 15, at 33 (Comm. Print 1958) (prepared by Professor Fritz Machlup) [hereinafter Machlup Report] (stating that the "widely accepted" and "fundamental economic justification of patents" is "to encourage inventing"); Mark A. Lemley, Ex Ante Versus Ex Post Justifications for Intellectual Property, 71 U. CHI. L. REV. 129, 129 (2004) ("The standard justification for intellectual property is ex ante . . . It is the prospect of the intellectual property right that spurs creative incentives.").

50 Eisenberg, supra note 2, at 1668.

51 See generally Hemel \& Ouellette, Beyond the Patents-Prizes Debate, supra note 32, at 333-44 (comparing ex ante incentives like grants to ex post incentives like patents).

52 See Lemley, Are Universities Patent Trolls?, supra note 9, at 621.

53 See, e.g., Meeting NSF's Technical Reporting Requirements, NAT'L SCI. Found. (May 22, 2013), http://www.nsf.gov/pubs/2013/nsf13094/nsf13094.jsp [https://perma.cc/Y975-S6JT]; Report Catalog, NAT'L INSTS. OF HEALTH, https:// report.nih.gov/catalog.aspx [https://perma.cc/A89N-ZLAU].

$54 C f$. Hemel \& Ouellette, Beyond the Patents-Prizes Debate, supra note 32, at 334-39 (discussing the disadvantage of providing ex post incentives like patents and prizes when researchers face capital constraints). 
We do not mean to imply that the ex ante justification for patents loses all of its force in the university context. Patents may help compensate researchers for the opportunity cost of their time, encouraging them to stay in science rather than pursuing more lucrative careers in finance. ${ }^{55}$ And more money may mean more research: the added incentive of a potential patent payout could provide enough extra incentive to university researchers to be worth the associated deadweight loss. ${ }^{56}$ Indeed, mixing patents and grants may help direct researchers' efforts toward those projects that are the most socially beneficial. ${ }^{57}$ But these theories have not been the justifications offered by Bayh-Dole proponents, and so far, they lack any clear supporting evidence. There is evidence that patent royalties matter in at least some respects: economists Saul Lach and Mark Schankerman have demonstrated that universities that provide faculty scientists with a larger percentage of patent royalties generate greater licensing income. ${ }^{58}$ But there is no evidence yet that the patent incentive increases research outputs, rather than simply creating a greater incentive for faculty to pursue lucrative licenses or directing scientists toward more applied projects (which might have additional negative social effects). 59

Qualitative evidence suggests that academic scientists are most concerned about maximizing their credibility and reputation, and that patents are valued to the extent they are viewed as enhancing credibility. The oft-cited work of sociologist Robert Merton focuses on idealized norms such as disinterestedness and communalism. ${ }^{60}$ Others have criticized this romanticized view and argued that academic scientists are bet-

55 Cf. Landon Thomas Jr., Traders with Ph.D.s, N.Y. TiMES, Feb. 23, 2016, at B1, B4 ("Harnessing Ph.D.-toting mathematicians to the most powerful computers money can buy has become the accepted way for hedge funds and banks to get a trading edge these days . . . .").

56 See Hemel \& Ouellette, Innovation Policy Pluralism, supra note 48 (manuscript at 17-18) (examining this theory).

57 See id. The consequences of mixing are not necessarily positive.

58 Saul Lach \& Mark Schankerman, Incentives and Invention in Universities, 39 RAND J. ECON. 403, 404-405 (2008); Saul Lach \& Mark Schankerman, Royalty Sharing and Technology Licensing in Universities, 2 J. EUR. ECON. Ass'N 252, 257 (2004).

59 One study of invention disclosures from eight U.S. universities from 1983 to 1999 casts some doubt on the hypothesis that Bayh-Dole diverted scientists from more "basic" research. Jerry G. Thursby \& Marie $\mathrm{C}$. Thursby, Has the Bayh-Dole Act Compromised Basic Research?, 40 RES. POL'Y 1077, 1081 (2011).

60 E.g., ROBERT K. MERTON, THE SOCIOLOGY OF SCIENCE (1973) (discussing scientific norms generally); Robert K. Merton, Priorities in Scientific Discovery: A Chapter in the Sociology of Science, 22 AM. Soc. REv. 635, 639 (1957) (discussing historical trends in scientific disputes over priority of discovery). 
ter viewed as rational strategists who seek to maximize credibility, which is measured through both concrete metrics such as publications and grants as well as more intangible markers of prestige. ${ }^{61}$ Under either view, patents are not a significant goal. More recent survey work also suggests that the financial incentive from patent royalties plays a small role in academic scientists' motivations and that a scientist's sentiments toward patenting are strongly guided by how her department values entrepreneurial activity. ${ }^{62}$

It is even theoretically possible that the financial incentive from potential patent royalties may decrease ex ante innovation incentives for university scientists. Yochai Benkler has argued that innovators are commonly motivated by "social-psychological rewards" and that extrinsic financial rewards may "crowd out" intrinsic motivations. ${ }^{63}$ For some academic scientists, the increased focus on profits in university research may decrease their other incentives for generating new knowledge, resulting in a smaller total incentive per dollar transferred from the public.

In sum, there is no strong evidence indicating whether Bayh-Dole skews ex ante incentives toward projects with either higher or lower social value. And there is certainly no evidence that any marginal gain in ex ante incentives is worth the subsequent deadweight loss in making the public "pay twice" for these inventions. ${ }^{64}$ This may well change, either due to new

61 See, e.g., BRUNo LATOUR \& STEVE WOOLGAR, LABORATORY LIFE: THE CONSTRUCTION OF SCIENTIFIC FACTS 187-201 (1986) (arguing that scientists are often motivated by a desire for credibility); S.B. Barnes \& R.G.A. Dolby, The Scientific Ethos: A Deviant Viewpoint, 11 EUR. J. Soc. 3, 7 (1970) (arguing that Merton's approach fails to identify constant normative structures within scientific activity); Michael J. Mulkay, Norms and Ideology in Science, 15 Soc. SCI. INFO. 637, 641 (1976) (discussing critiques of Merton's work and providing counterexamples). For an excellent discussion of how Bayh-Dole debates should incorporate this nonMertonian work, see Tai-Jan Huang, Beyond Patent Royalties: Putting Academic Scientists Back into the Bayh-Dole Debate (Jan. 6, 2016) (unpublished manuscript) (on file with authors).

62 See Alice Lam, What Motwates Academic Scientists to Engage in Research Commercialization: 'Gold', 'Ribbon' or 'Puzzle'?, 40 RES. POL'Y 1354, 1366 (201 1); Brian J. Love, Do University Patents Pay Off? Evidence from a Survey of University Inventors in Computer Science and Electrical Engineering, 16 YALE J.L. \& TECH. 285, 286 (2014); Jason Owen-Smith \& Walter W. Powell, To Patent or Not: Faculty Decisions and Institutional Success at Technology Transfer, $26 \mathrm{~J}$. TECH. TRANSFER 99, 102 (2001); Catherine Searle Renault. Academic Capitalism and University Incentives for Faculty Entrepreneurship, 31 J. TECH. TRANSFER 227, 229 (2006).

63 YOCHAI BENKLER, THE WEALTH OF NETWORKS: HOW SOCIal PRODUCTION TRANSFORMS MARKETS AND FREEDOM 92-98 (2006).

64 The concern that Bayh-Dole makes the public "pay twice" is one of the most frequent critiques of Bayh-Dole. See, e.g., Bd. of Trs. of Leland Stanford Jr. Univ. v. Roche Molecular Sys., 131 S. Ct. 2188, 2201 (2011) (Breyer, J., dissent- 
empirical work or to changes in university research practices. For example, perhaps some university research will move to a model in which research grants reimburse only a small percentage of the costs of inventing. ${ }^{65}$ Indeed, we hope this Article will inspire Bayh-Dole defenders to think more seriously about how to best justify patents on federally funded inventions in those cases when they are unnecessary for commercialization. But for now, given the certain costs that must be incurred to receive what is at best a speculative benefit, ex ante incentives are not a compelling justification for university patents. 66

\section{Ex Post Commercialization}

The more convincing justification for university patents is that they provide an ex post incentive to commercialize inventions that would otherwise sit "in warehouses gathering dust." 67 Ex post theories have a long history in debates over the economics of patenting, even outside the university context. Indeed, Fritz Machlup's famous 1958 review of the patent system gives preeminent status to ex post theories:

The thesis that patent protection is needed as a stimulus to invention has been first supplemented and then replaced by the thesis that it is needed as a stimulus to the practical use of new inventions in industry. Financing the work that leads to the making of an invention may be a relatively small venture compared with that of financing its introduction, because costly development work, experimentation in production and experimentation in marketing may be needed before the commercial exploitation of the invention can begin. The risks involved may be too great to be undertaken except under the shelter of a monopoly grant. 68

ing); Rochelle Cooper Dreyfuss, Collaborative Research: Conflicts on Authorship, Ownership, and Accountability, 53 VAND. L. REV. 1161, 1194 (2000); Eisenberg, supra note 2, at 1666; Bhaven N. Sampat \& Frank R. Lichtenberg, What Are the Respective Roles of the Public and Private Sectors in Pharmaceutical Innovation?, 30 HEALTH AFF. 332, 333 (2011).

$65 C f$. Suzanne Scotchmer, Patents in the University: Priming the Pump and Crowding Out, LXI J. INDUS. ECON. 817, 842 (2013) (proposing a requirement of university matching for grant awards, and noting that "the federal government does not give funds on this basis").

66 Indeed, a discussion of many benefits of Bayh-Dole by Stanford's technology transfer office does not even attempt to argue that the patent incentive will cause academics to produce more or better research. See Hans Wiesendanger, $A$ History of OTL: Overview, STANFORD UNIV. OFFICE OF TECH. LICENSING (2000), http:// otl.stanford.edu/about/about_history.html [https://perma.cc/9K2L-KFRA].

67 Innovation's Golden Goose, supra note 4; see also Chester G. Moore, Killing the Bayh-Dole Act's Golden Goose, 8 Tul. J. TECH. \& INTELl. PROP. 151, 155-56 (2006) (concurring with The Economist's assessment).

68 See Machlup Report, supra note 49, at 36-37. 
This ex post function has since been promoted and explored in great detail by numerous legal scholars. ${ }^{69}$

The commercialization argument takes on even more significance in the university context (where ex ante incentives are less important), and this focus is expressly stated in the text of the Bayh-Dole Act. The first-listed goal in the statute is "to promote the utilization of inventions arising from federally supported research or development," and another goal is to "protect the public against nonuse . . . of inventions."70 The legislative history also focuses on commercialization. Senator Birch Bayh was concerned with the "[h]undreds of valuable medical, energy, and other technical discoveries" that were "sitting unused." 71 The House Report specified that the goal of the Act was to "encourage private industry to utilize government funded inventions through the commitment of the risk capital necessary to develop such inventions to the point of commercial application."72 As explained in a Congressional Research Service report reviewing the rationale of the Bayh-Dole Act, "it was widely argued that without title (or at least an exclusive license) to an invention and the protection it conveys, a company would not invest the additional, and often substantial time and money necessary to commercialize a product or pro-

69 See generally Michael Abramowicz, The Danger of Underdeveloped Patent Prospects, 92 CORNELL L. REV. 1065 (2007) (discussing the problem of insufficient remaining patent term to incentivize ex post commercialization); Michael Abramowicz \& John F. Duffy, Intellectual Property for Market Experimentation, 83 N.Y.U. L. REV. 337, 396-408 (2008) [hereinafter Abramowicz \& Duffy, Market Experimentation] (discussing.the role of patents in encouraging post-patenting commercialization and market experimentation); F. Scott Kieff, Property Rights and Property Rules for Commercializing Inventions, 85 MinN. L. REV. 697, 703 (2001) (" $[T]$ he treatment of patents as property rights is necessary to facilitate investment in the complex, costly, and risky commercialization activities required to turn nascent inventions into new goods and services."); Edmund W. Kitch, The Nature and Function of the Patent System, 20 J.L. \& ECON. 265, 276-77 (1977) (discussing the importance of patents for incentivizing commercialization); Ted Sichelman, Commercializing Patents, 62 STAN. L. REV. 341 (2010) (arguing that patents are important for, and yet often insufficient for, commercializing inventions, and proposing a new form of commercialization patent). For a critique of ex post theories, see Lemley, supra note 49 , at 131-32.

7035 U.S.C. $\$ 200$ (2012). Other goals are to encourage small businesses, domestic manufacture, and industry-university collaborations. The statute also recognizes the value of competition and of unimpeded cumulative innovation with the goal of "promot[ing] free competition and enterprise without unduly encumbering future research."

71124 CONG. REC. 29,122 (1978) (statement of Sen. Bayh).

72 H.R. REP. NO. 96-1307, pt. 1, at 3 (1980). 
cess for the marketplace." 73 Relatedly, Bayh-Dole proponents argue that patents are needed to encourage university researchers to transfer their tacit knowledge to industry. ${ }^{74}$

A central concern motivating Bayh-Dole is that without patent protections there would be a "first-commercializer disadvantage." 75 Without the patent protection offered by an exclusive license, the first firm to commercialize would worry that it would not be able to recoup the fixed costs of its commercialization because competitors would subsequently enter, free-riding on its commercialization efforts, and drive the price down to the marginal cost of practicing the now-commercialized invention. When a substantial first-commercialization disadvantage exists, no firm in an industry might be willing to bring to market socially valuable inventions without some way to limit competitors from free-riding on their commercialization efforts. Hearings on the bill noted just these kinds of non-commercialization examples such as the federal government's unsuccessful effort to convince firms to commercialize penicillin despite the lack of patent protection, until World War II finally spurred the government to commercialize the drug itself. ${ }^{76}$ Arguments against the bill also illustrate that commercialization was the primary goal. ${ }^{77}$

Defenders of the current Bayh-Dole system continue to emphasize commercialization. Justice Breyer has asserted that Bayh-Dole patents are only worth their significant cost for "a special public policy reason": the Act "seeks to encourage [grant recipients] to commercialize inventions that otherwise

73 Wendy H. SCHACHT, CONG. RESEARCH SERV., RL32076, THE BayH-DOLE ACT: Selected Issues in Patent Policy and the Commercialization of TeChnology 2 (2012).

74 See Rai et al., supra note 12, at 1550-51 ("Another major argument often advanced in favor of patents is that the prospect of licensing royalties induces university researchers to work with industry licensees and thereby transfer tacit knowledge necessary for commercialization.").

75 Cf. Abramowicz \& Duffy, Market Experimentation, supra note 69, at 378 (discussing the "first-mover" disadvantage).

76 See University and Small Business Patent Procedures Act: Hearing on S. 414 Before the S. Comm. on the Judiciary. 96th Cong. 146-47 (1979) (testimony of Dr. Betsy Ancker-Johnson, Vice President, Gen. Motors, Envtl. Activities Staff); id. at 179 (testimony of Frederick N. Andrews, Vice President for Research, Purdue Univ.).

77 See, e.g., Peter S. Arno \& Michael H. Davis, Why Don't We Enforce Existing Drug Price Controls? The Unrecognized and Unenforced Reasonable Pricing Requirements Imposed upon Patents Deriving in Whole or in Part from Federally Funded Research, 75 TuL. L. REV. 631, 658 (2001) ("Representative Jack Brooks (Texas), perhaps the harshest critic of the proposed legislation, expressed doubts that granting an exclusive license to industry after paying to develop a patentable invention was an incentive to commercialize."). 
might not realize their potentially beneficial public use."78 Stanford's Office of Technology Licensing-one of the most effective university technology transfer offices by many metricsargues that "licensing often is the only way a new invention will ever become a product."79 The Association of University Technology Managers (AUTM) argues that "few [university] inventions were commercialized" before Bayh-Dole (though it might be more accurate to say that few university inventions were patented and licensed in an easily quantifiable way). ${ }^{80}$ AUTM has collected over 500 inspiring stories of successful licensing of university patents for its Better World Project, ranging from a device that enables severely disabled people to express themselves by controlling a computer screen with eye movements (based on research at Boston College) to a method of growing trees three times faster and with less water by starting their growth in a laboratory (from Washington State University). ${ }^{81}$

We do not dispute that exclusive patent rights are needed for efficient commercialization of at least some-and perhaps most-university inventions. As explained in the Introduction, this theory is particularly compelling in the context of pharmaceuticals that require expensive clinical trials to bring to market but that are comparatively cheap to replicate. ${ }^{82}$ And there may be some cases in which the inventor's tacit knowledge is indispensable for technology transfer. ${ }^{83}$ But commercialization theory cannot justify patents for products that firms

78 Bd. of Trs. of Leland Stanford Jr. Univ. v. Roche Molecular Sys., 563 U.S. 776, 797 (2011) (Breyer, J., dissenting); see also id. at 782 (majority opinion) ("In 1980, Congress passed the Bayh-Dole Act to "promote the utilization of inventions arising from federally supported research' . . . (quoting 35 U.S.C. § 200 (2012)); In re Roche Molecular Sys., Inc., 516 F.3d 1003, 1008 (Fed. Cir. 2008) ("The purpose of the Bayh-Dole Act is as an incentive, not a bar, to university-industry collaboration and commercial development through licensing . . . .").

79 Wiesendanger, supra note 66.

80 The Bayh-Dole Act: It's Working, Ass'N OF UNIV. TECH. MANAGERS, http:// www.autm.net/AUTMMain/media/Advocacy/Documents/BayhDoleTalking PointsFINAL.pdf [https://perma.cc/5BD2-EPC5].

81 Featured Stories, ASS'N OF UNIV. TECH. MANAGERS BETTER WORLD PROJECT, http://www.betterworldproject.org/featured-stories [https://perma.cc/T4K5$44 \mathrm{MX}$. Many of these stories focus on the startups generated by university licenses, perhaps for political economy reasons. While related to commercialization theory, the startup-generating function of Bayh-Dole patents could be viewed as a normative theory of its own. See Rai et al., supra note 12, at 1555 ("Even if patenting and exclusive licensing of software do not facilitate commercialization per se, one might argue that exclusive licenses to university patents are useful for software start-ups, and promoting such start-ups is a socially valuable goal."). We think this issue, like the other justifications for Bayh-Dole we discuss, deserves more empirical attention.

82 See supra notes 30-31 and accompanying text.

83 See supra note 74 and accompanying text. 
are eager to develop without exclusivity, such as when firms developed a product under inexpensive nonexclusive licenses or without awareness of the patent at all. Robin Feldman and Mark Lemley have shown that ex post licensing demands are unlikely to generate technology transfer. ${ }^{84}$ And as Mark Lemley has noted, "the validity of commercialization theory depends a great deal on the industry in question and the particular nature of the technology." 85 The problem is that no one has figured out how many other inventions look like pharmaceuticals. We return to this problem in subpart II.B, but first, the remainder of this subpart describes a few alternative justifications that have been put forth for university patents.

\section{Disclosure, Transactions, and Signals}

In addition to providing incentives to invent and commercialize inventions, scholars have noted that patents may facilitate disclosure and exchange of information about new technologies. ${ }^{86}$ Disclosure of technical information is often cited by Supreme Court as one of the key reasons we have patents. ${ }^{87}$ As one of us has explained, scholars have often underestimated the benefit provided by patent disclosures, but these benefits cannot justify the patent system. ${ }^{88}$ A different strand of disclosure literature emphasizes that patents allow

84 See Robin Feldman \& Mark A. Lemley, Do Patent Licensing Demands Mean Innovation?, 101 IOWA L. REV. 137, 174-76 (2015).

85 Lemley, Are Universities Patent Trolls?, supra note 9, at 622-23.

86 For a review of these more recent justifications for the patent system, see generally Stephen Yelderman, Coordination-Focused Patent Policy, 96 B.U. L. REV. (forthcoming 2016), http://ssrn.com/abstract=2481025 [https://perma.cc/ 9S8E-MJTF].

87 See, e.g., Festo Corp. v. Shoketsu Kinzoku Kogyo Kabushiki Co., 535 U.S. 722,736 (2002) ("IE]xclusive patent rights are given in exchange for disclosing the invention to the public."); J.E.M. Ag Supply, Inc. v. Pioneer Hi-Bred Int'l, Inc., 534 U.S. 124, 142 (2001) ("The disclosure required by the Patent Act is "the quid pro quo of the right to exclude." (quoting Kewanee Oil Co. v. Bicron Corp., 416 U.S. 470, 484 (1974))); Bonito Boats, Inc. v. Thunder Craft Boats, Inc., 489 U.S. 141, 151 (1989) ("In consideration of [the invention's] disclosure and the consequent benefit to the community, the patent is granted."); Kewanee Oil, 416 U.S. at 481 (stating that additions from patent disclosures "to the general store of knowledge are of such importance ... that the Federal Government is willing to pay the high price of 17 years of exclusive use for its disclosure").

88 See Lisa Larrimore Ouellette, Do Patents Disclose Useful Information?, 25 HARV. J.L. \& TECH. 531, 545 (2012) [hereinafter Ouellette, Do Patents Disclose Useful Information?; see also Machlup Report, supra note 49, at 33 (noting the "poor reception in economic literature" for disclosure theory); Alan Devlin, The Misunderstood Function of Disclosure in Patent Law, 23 HARV. J.L. \& TECH. 401, $403(2010)$ ("As a primary function of [the patent] system, disclosure is both ineffective and potentially poisonous to larger social goals ....."). 
disclosure through channels outside the patent specification by solving Arrow's information paradox-though this theory too faces empirical and theoretical challenges. ${ }^{89}$ Yet another disclosure argument is that patents act as signals that allow firms to credibly convey information to third parties-though it is unclear that patent laws do better than securities laws in fulfilling this role. ${ }^{90}$

Whatever weight these arguments pull in justifying the patent system in general, we think they have little force for federally funded inventions. Researchers already have strong incentives to disclose their results through peer-reviewed publications. ${ }^{91}$ The grants themselves often require disclosure of the research results, ${ }^{92}$ and in a world without Bayh-Dole, grantees could be required to make patent-like disclosure of their findings. The Bayh-Dole regime may even depress or delay academic disclosure if scientists worry that non-patent disclosures may limit their later ability to patent. 93

Publications and grants also act as strong signals to third parties about researchers' and universities' innovativeness. It may be, as Dan Burk suggests, that the signaling value of patents helps descriptively explain why universities frequently engage in patenting activities that seem economically irrational, ${ }^{94}$ but this certainly does not justify the costs of university patenting.

\section{Revenue for University Research}

An explanation that might make more sense in the university context-and that is distinct from justifications for the patent system in general-is that the revenues from licensing university patents can be used to provide additional funding for other scientific research. The Bayh-Dole Act specifies that "the balance of any royalties or income earned by the contractor with respect to subject inventions, after payment of expenses (including payments to inventors) incidental to the administra-

89 For a summary of this literature, see Hemel \& Ouellette, Beyond the Patents-Prizes Debate, supra note 32, at 357.

90 See id. at 358.

91 See Rai, supra note 24, at 119 ("Well before Bayh-Dole allowed universities to seek patent rights on their inventions. American research universities were publishing pioneering research.").

92 See supra note 53 and accompanying text.

93 See Margo A. Bagley, Academic Discourse and Proprietary Rights: Putting Patents in Their Proper Place, 47 B.C. L. REV. 217, 240-41 (2006).

94 Dan L. Burk, On the Sociology of Patenting, 101 MiNN. L. REv. (forthcoming 2016) (manuscript at 4-5), http://ssrn.com/abstract=2740947 [https:// perma.cc/C78J-5L6S]. 
tion of subject inventions, be utilized for the support of scientific research or education."95 Stanford's technology transfer office lists revenue as its first argument in favor licensing university patents:

[W] hile the federal government has traditionally been the major sponsor of basic research conducted in universities, the current trend is to limit such funding. Universities thus are faced with the need to develop alternate sources of funding or to curtail their research activities. Licensing income can be a critical source of much-needed unrestricted funding. ${ }^{96}$

A former technology-transfer officer described revenue generation as "the unstated aim" of university patent licensing. ${ }^{97} \mathrm{Pe}-$ ter Detkin, whose firm Intellectual Ventures has licensed "thousands of university patents" and paid "about US\$1 10 million to universities and government researchers" in the past ten years, argues that these licenses allow universities "to recoup their research dollars and reward their inventors." 98

For some, this argument is less easily dismissed than the idea that Bayh-Dole patents provide significant ex ante incentives to individual researchers or disclosure benefits. Academics often find it hard to oppose a new source of university research support in an era of declining (and often risk-averse ${ }^{99}$ ) federal funding. Revenue from patent licensing is an unrestricted source that some universities may be able to invest even more wisely than federal grant agencies. This revenue gain may be an underappreciated benefit of the Bayh-Dole Act. But we are not convinced that this benefit can bear the weight of independently justifying university patents that are unnecessary for commercialization.

First, it is worth bearing in mind that this revenue stream is not free; as one of us has previously explained, the higher price of patented inventions is equivalent to a "shadow tax" that is transferred from the consumers of those inventions to the rightsholders without passing through the federal

\footnotetext{
9535 U.S.C. \& 202(c)(7)(C) (2012).

96 Wiesendanger, supra note 66.

97 Ledford, Universities Struggle to Make Patents Pay, supra note 7, at 471 (quoting Melba Kurman, "a former technology-transfer officer at Cornell University").

98 Peter Detkin, Correspondence, Patents: Universities Are Right to Partner, 502 NATURE 448 (2013).

99 For a clever empirical study suggesting that more federal agencies should adopt a riskier, long-term strategy in awarding grants, see Pierre Azoulay et al., Incentives and Creativity: Evidence from the Academic Life Sciences, 42 RAND J. ECON. 527 (2011).
} 
budget. ${ }^{100}$ But from the public's perspective, there is little difference between the patent shadow tax and an actual sales tax, so this on-budget/off-budget distinction ought not matter for innovation policy design. ${ }^{101}$ Furthermore, funding research through broad-based taxation rather than a concentrated tax on users of the resulting invention is generally more efficient, so it is hard to make the case for shifting funding of university research away from tax-funded grants and toward patent rents. ${ }^{102}$

University technology transfer also appears to be a highly inefficient way to raise revenue for university research. In fact, most universities do not appear to generate revenue at all: one report estimated that of the 155 universities reporting to the AUTM survey, 130 did not generate enough licensing revenue in 2012 to cover their expenses that year. ${ }^{103}$ As many as $95 \%$ of university patents are unlicensed, ${ }^{104}$ suggesting that technology transfer offices are ineffective at choosing which inventions to patent or that they are patenting for non-monetary reasons, such as the signaling goal discussed above. Outgoing AUTM President Fred Reinhart recently stated, "We don't file patent applications to get rich. We don't file patent applications for any reason other than [that] our licensees want . . . a protected time period to justify the investment they're going to make in creating a product or a service." 105 Revenue might be increased through the patent litigation strategies noted in the Introduction, ${ }^{106}$ but litigation seems like an even more ineffi-

100 Hemel \& Ouellette, Beyond the Patents-Prizes Debate, supra note 32, at 312-13, 371-73.

101 Id. at 371.

102 See Gene M. Grossman \& Edwin L.-C. Lai, International Protection of Intellectual Property, 94 AM. ECON. REv. 1635, 1640 (2004); Amy Kapczynski, Intellectual Property's Leviathan, LAW \& CONTEMP. PROBS., Fall 2014, at 131, 133.

103 WALTER D. VALDIVIA, UNIVERSITY START-UPS: CRITICAL FOR IMPROVING TECHNOLOGY TRANSFER 9 (Ctr. for Tech. Innovation at Brookings, 2013); see also Ashley J. Stevens, Do Most Academic Institutions Lose Money on Technology Transfer?, Presentation at 'Annual Meeting of the Tech. Transfer Soc'y (2005) at 31, http:// sites.kauffman.org/pdf/tt/Stevens_Ashley.pdf [https://perma.cc/G9Z5-HVCF] (reporting that, from 1992-2004 just over half of university technology transfer offices had a "[p]ositive [f]inancial [c]ontribution").

104 Ledford, Universities Struggle to Make Patents Pay, supra note 7, at 472 ("Joy Goswami, assistant director of the technology-transfer office at the University of Delaware in Newark, estimates that. only about $5 \%$ of patents are licensed at most universities. The rest are a drain on office resources, he adds, because of required maintenance and legal fees.").

105 Gene Guinn, Exit Interview: A Conversation with Outgoing AUTM President Fred Reinhart, IPWATCHDOG (Feb. 14, 2016), http://www.ipwatchdog.com/2016/ 02/14/autm-president-fred-reinhart/id=66075 [https://perma.cc/2J7A-RBDV].

106 See supra notes 7-12 and accompanying text. 
cient method of funding university research. As Reinhart stated on behalf of AUTM, "We don't like litigation. There's nothing great about it. We're not set up to engage in it. It's expensive. It's time-consuming, distracting and it doesn't look good for anybody to be involved with litigation . . . ."107

These sobering statistics do not mean that the revenuerecycling aspect of Bayh-Dole could not become an important benefit. According to AUTM statistics, the gross licensing income reported by U.S. universities and nonprofit research institutes has been increasing faster than their legal fees. ${ }^{108} \mathrm{But}$ if revenue generation is the best justification for many Bayh-Dole patents, then we think this demands a serious public debate about whether this benefit is worth the significant costs, whether Bayh-Dole could be restructured to make this revenue-generation function more efficient, and whether there are better ways to achieve this goal. ${ }^{109}$

\section{International Considerations}

In a separate article, one of us, along with Daniel Hemel, describes an overlooked benefit of Bayh-Dole: by allowing the United States to internalize some of its grant spending, Bayh-Dole may encourage more efficient levels of grant spending in the first place. ${ }^{110}$ Here, we review this new "internalization theory" and address how it might affect our proposal.

A rational U.S. policymaker should invest in direct $R \& D$ spending on a given topic up to the point that the marginal benefits to the United States exceed the marginal cost. But the results of this $R \& D$ spending often have benefits for citizens of other countries, and unless these foreign benefits are taken

107 Quinn, supra note 105. Additionally, even if some universities are successful in monetizing their patent portfolios, it is far from clear that this revenue stream is correlated with the amount that the university's research should be subsidized going forward.

108 See Hemel \& Ouellette, Bayh-Dole Beyond Borders, supra note 48 (manuscript at 15 fig.1) (graphing data from Statistics Access for Technology Transfer (STATT) Database, supra note 16).

109 See, e.g., Jacob H. Rooksby, Innovation and Litigation: Tensions Between Universities and Patents and How to Fix Them, 15 YALE J.L. \& TECH. 312, 312 (2013) (proposing "allow[ing] universities to enjoy the revenue-generation aspect of patent ownership while freeing them from the legal compulsion to participate as co-plaintiffs with their exclusive licensees in enforcement actions").

110 Hemel \& Ouellette, Bayh-Dole Beyond Borders, supra note 48; see also Daniel J. Hemel \& Lisa Larrimore Ouellette, Knowledge Goods and Nation-States, 101 MiNN. L. REV. (forthcoming 2016), http://ssrn.com/abstract=2745632 [https://perma.cc/3EPW-Y4BY] [hereinafter Hemel \& Ouellette, Knowledge Goods and Nation-States] (noting the implications of this benefit for debates over IP treaties). 
into account, the rational U.S. investment level will be less than the globally optimal amount. This hypothesis of underinvestment in knowledge production in the absence of global coordination is the conventional economic justification for international patent treaties. ${ }^{111}$ (Most importantly, almost every country-and every economically: significant country-is a member of the World Trade Organization and thus must comply with the twenty-year patent requirement of the Agreement on Trade-Related Aspects of Intellectual Property Rights, or TRIPS. ${ }^{112}$ ) Under this account of international IP law, as explained by the late innovation economist Suzanne Scotchmer, "harmonized intellectual property protections allow countries to recoup some of the benefits they confer on foreign consumers," and thus "there may be too little public sponsorship and too much intellectual property" at the domestic level. ${ }^{113}$

Those harmonized intellectual property protections, however, may actually encourage IP alternatives like public sponsorship:

[I]t is worth noting that the common concern that allowing IP protection on publicly supported works requires U.S. taxpayers to "pay twice" overlooks the point that not allowing IP protection permits non-U.S. consumers to avoid paying at all. When combined with international IP treaties, Bayh-Dole regimes may encourage states to increase direct public funding for research, alleviating Scotchmer's concern that IP treaties at the international level will cause "too little public sponsorship" at the domestic level. ${ }^{114}$

Unless government grantees can obtain patent protection for inventions generated by government-funded research, the

111 See, e.g., Suzanne Scotchmer, The Political Economy of Intellectual Property Treaties, 20 J.L. ECON. \& ORG. 415, 420 (2004) (explaining that absent global coordination, "both public sponsors and private investors have deficient incentives to invest, relative to what is efficient" due to "uncompensated externalities abroad").

112 See Agreement on Trade-Related Aspects of Intellectual Property Rights arts. 27, 33, Apr. 15, 1994, Marrakesh Agreement Establishing the World Trade Organization. Annex 1C, 1869 U.N.T.S. 299, 33 I.L.M. 1197 (requiring patents "in all fields of technology" with protection lasting at least twenty years from filing); Members and Observers of the WTO. WORLD TRADE ORG., https://www.wto.org/ english/thewto_e/countries_e/org6_map_e.htm [https://perma.cc/E7ZH-DYZT] (last updated July 29, 2016) (showing the 164 members of the WTO on a map); Accession in Perspective, WORLD TRADE ORG., https://www.wto.org/english/ thewto_e/acc_e?/cbt_course_e/c1slp1_e.htm [https://perma.cc/9LZ5-NY32] (noting that WTO members represent over $96 \%$ of global GDP and trade).

113 ' Scotchmer, supra note 111 , at $415,436$.

114 Hemel \& Ouellette, Knowledge Goods and Nation-States, supra note 110; see Hemel \& Ouellette, Bayh-Dole Beyond Borders, supra note 48 (describing this internalization theory of Bayh-Dole in more detail). 
United States would have no practical way of internalizing the positive externalities conferred on consumers in other countries who use products produced through U.S. taxpayer-financed research. By allowing the United States to internalize benefits that federally funded inventions bring to consumers abroad, the Bayh-Dole Act plausibly leads U.S. lawmakers to invest more in public research funding in the first place. ${ }^{115}$

We naturally have no quibble with this account, though it remains untested, and this benefit may be outweighed by the costs of patenting in many cases. ${ }^{116}$ Here, we simply note that if this novel account is in fact a significant justification for many Bayh-Dole patents-in particular, those for which exclusivity is unnecessary for commercialization-then it would require a change in Bayh-Dole implementation. The optimum Bayh-Dole regime might then involve more significant patenting abroad and use of our market test proposal only for domestic users of university inventions. We thus will cabin this consideration for now. But if further research provides additional support for the theory that payments from foreign consumers increase the willingness of federal policymakers to provide more efficient levels of direct $R \& D$ support in the first place, then it may be worth limiting our proposal to the domestic sphere. ${ }^{117}$

\section{Copyleft-Style Patent Licensing}

A final potential benefit of Bayh-Dole patents is an extension of the point that exclusivity is sometimes unnecessary for commercialization. In some cases, a technology might develop most efficiently not only without constraints on the initial basic inventions that originated from federally funded university research, but also without subsequent patenting by the private firms that use the technology. Universities can help with this goal by patenting foundational technologies and then freely licensing them under the condition that licensees use the same open license terms with related innovations. This approach

115 Hemel \& Ouellette, Bayh-Dole Beyond Borders, supra note 48 (discussing possible mechanisms through which this might occur).

116 See id. This is a specific example of a more general point about IP laws made by Brett Frischmann and Mark Lemley: "even where internalizing externalities increases incentives to invest, the social costs of relying on property rights to do so still may exceed the benefits." Brett M. Frischmann \& Mark A. Lemley, Spillovers, 107 COLUM. L. REV. 257, 258 (2007).

117 Note that the implementing regulations for the Bayh-Dole Act allow agencies to take title to the invention in any country in which a university does not pursue protection. 37 C.F.R. $\S 401.14$ (d)(3) (2015). 
was pioneered in the software context with copyright licenses, where it came to be known as "copyleft." 118

The effectiveness of such a strategy is limited by important differences between copyrights and patents. Most notably, copyright affixes automatically and costlessly, whereas patents are expensive and time-consuming to obtain. ${ }^{119}$ As David Grewal has described, these difficulties caused synthetic biology pioneers to abandon their initial plans to create an affirmative copyleft-style licensing commitment for basic synthetic biology building blocks in favor of a strategy of simply dedicating these inventions to the public domain. ${ }^{120}$

Universities may have more success in using their upstream patents to demand downstream licensing commitments related to access in low-income countries. As one of us has demonstrated, the majority of FDA-approved pharmaceuticals with university patents also have a follow-on patent with no university assignee. ${ }^{121}$ A university that develops an initial drug candidate and then licenses it to a pharmaceutical company for clinical trials could require that no follow-on patents related to that drug be filed in certain countries. ${ }^{122}$ The same approach could also be used in non-pharmaceutical areas, such as green technologies. ${ }^{123}$

The ability to engage in these copyleft-style strategies may be an important benefit of some university patents. ${ }^{124}$ But note that unlike the features of university patents described above, this benefit depends on limiting the constraints on production that patents impose. It is thus not an argument against using our market test. Rather, by demonstrating when exclusivity is unnecessary for commercialization, our market

118 See YOCHAI BENKLER, THE WEALTH OF NETWORKS 65 (2006).

119 See Lexmark Int'1 v. Impression Prods., 816 F.3d 721, 761 (Fed. Cir. 2016) (en banc) ("Patents involve costly government-approval processes ... . Copyrights are different. They generally spring into being without any government approval .....").

120 David Singh Grewal, Before Peer Production: Infrastructure Gaps and the Architecture of Openness in Synthetic Biology, 19 STAN. TECH. L. REV. (forthcoming 2017) (manuscript at 22-37).

121 Ouellette, How Many Patents Does It Take To Make a Drug?, supra note 30, at 319 .

122 See id. at 322; see also infra notes 171-172 and accompanying text (describing the success universities have had in promoting access to their technologies in developing countries).

123 See Ouellette, Addressing the Green Patent Global Deadlock, supra note 6.

124 See generally Peter Lee, Toward a Distributive Commons in Patent Law, 2009 WIS. L. REV. 917 (describing the role of noncommercial, humanitarian norms in university patenting). 
test may illuminate those areas of technology for which copyleft-style patent licenses might be most fruitful.

B. When Is an Exclusive Right Necessary for Commercialization?

As explained in subpart I.A, while there are numerous theories of Bayh-Dole patents that deserve more attention, the only case in which there is currently convincing evidence that the social costs of patents are worth bearing is when an exclusive right is necessary for commercialization. Yet it is unclear when that condition is satisfied. Bayh-Dole has certainly increased the number of quantifiable licenses of university patents, such as those detailed in AUTM's Better World Project. ${ }^{125}$ But how many of these inventions would have been quickly adopted anyway even if they hadn't been patented? Were the ideas of controlling a computer screen with eye movements and growing trees faster in laboratories so valuable that firms would have marketed these inventions without patent protection, or were the markets for these ideas so risky and uncertain that no firm would have entered without a patent? In other words, are these inventions more like traditional pharmaceuticals or more like the recombinant DNA techniques covered by the Cohen-Boyer patents?

It is impossible to observe the counterfactual parallel universe in which these inventions were not patented, so estimating the causal effect of exclusive patent rights in any given historical case is challenging. But we can at least conclude with confidence that exclusive rights are not always needed: the fact that universities have often licensed inventions on a nonexclusive basis is evidence that an exclusive patent right was not necessary. In fact, over sixty percent of the thousands of licenses reported each year on a survey of technology transfer offices are nonexclusive. ${ }^{126}$ As explained above, these licenses (and the underlying patents) are likely not welfare enhancing. ${ }^{127}$

\footnotetext{
125 See supra note 81.

126 See supra note 16 . As noted there, we do not know what proportion of . Bayh-Dole revenue these nonexclusive licenses generate.

127 Of course, it is possible that the fees for these nonexclusive licenses were set high enough to restrict quantity to the monopoly level, in which case they are effectively equivalent to exclusive licenses. But it seems unlikely to us that universities and their licensees would regularly choose such a structure over an actual exclusive license.
} 
The high-profile litigations mentioned above help illustrate these critiques. ${ }^{128}$ The inventions at issue were funded by taxpayers and published in scientific journals, so it is difficult to argue that patents were needed to incentivize these university scientists to create and disclose these inventions. Most of the funding for the high-tech patents asserted by Carnegie Mellon, ${ }^{129}$ Wisconsin, ${ }^{130}$ and Boston University ${ }^{131}$ was provided by the National Science Foundation (NSF). Boston University sought patent protection in Japan and the European Patent Office, ${ }^{132}$ so there may be some internalization benefit from these foreign patents, but Wisconsin and Carnegie Mellon appear to have only patented their inventions domestically. ${ }^{133}$ And given that the universities licensed these inventions 128 Supra notes 9-12 and accompanying text. For additional examples of uni-
versities using patents in ways that seem contrary to the public-spirited goal of
commercialization, see Lee, Patents and the University, supra note 21 .

129 U.S. Patent No. 6,201,839 col. 1 1. 13-14 (filed Apr. 3, 1998); U.S. Patent No. 6,438,180 col. 1 1. 13-14 (filed Mar. 1, 1999); see Carnegie Mellon Univ. v. Marvell Tech. Grp., 807 F.3d 1283, 1288-89 (Fed. Cir. 2015) (listing patents); Aleksandar Kavcic \& José M.F. Moura, Correlation-Sensitive Adaptive Sequence Detection, 34 IEEE TRANSACTIONS ON MAGNETICS 763, 763 (1998) (noting support from the same NSF grant listed in the patents); Aleksandar Kavcic \& Josê M. F. Moura, Matrices with Banded Inverses: Inversion Algorithms and Factorization of Gauss-Markov Processes, 46 IEEE TRANSACTIONS ON INFO. THEORY 1495, 1495 (2000) (showing the same); Aleksandar Kavcic \& José M. F. Moura, The Viterbi Algorithm and Markov Noise Memory, 46 IEEE TRANSACTIONS ON INFO. THEORY 291. 291 (2000) (showing the same).

130 U.S. Patent No. 5,781,752 col. 1 1. 5-9 (filed Dec. 26, 1996) (also noting support from the Army (ARPA) and the Navy (ONR)); see Wisconsin Alumni Research Found. v. Apple, Inc., No. 14-CV-062-WCC, 2015 WL 5009944, at * 1 (W.D. Wis. Aug. 20, 2015) (listing patent); Andreas Moshovos et al., Dynamic Speculation and Synchronization of Data Dependences, PROC. 24TH ANN. INT'L SYMP. ON COMPUTER ARCHITECTURE, May 1997, at 181 (noting support from the same grants listed in the patent).

131 See U.S. Patent No. 5,686,738 col. 1 1. 9-10 (filed Jan. 13, 1995) (claiming priority to an application filed Mar. 18, 1991); T. Lei et al., Epitaxial Growth of Zinc Blende and Wurtzitic Gallium Nitride Thin Films on (001) Silicon, 59 APPLIED PHYSICS LETTERS 944, 946 (1991) (noting NSF support for the invention described in the patent); see also Tim Stoddard, Green Light on Blue Light: Blue Light Technology Remains BU's Intellectual Property, B.U. BRIDGE (Dec. 13, 2002), https:// www.bu.edu/bridge/archive/2002/12-13/bluelight.htm [https://perma.cc/ NTR2-WEV6] (explaining why B.U. has patent rights to the blue LED based on this 1991 publication, even though another scientist, Shuji Nakamura, typically receives scientific credit-as he did in receiving the 2014 Nobel Prize in Physics).

132 See Highly Insulating Monocrystalline Gallium Nitride Thin Films, GoogLE PATENTS, https://patents.google.com/patent/US5686738A [https://perma.cc/ 96EE-ZN3U] (containing links under "[a]lso published as" to parallel patents granted in Japan and the European Union).

133 See Advanced Search, ESPACENET, http://worldwide.espacenet.com/advancedSearch [https://perma.cc/8ANG-4VEA] (search "Publication number" for "US6201839" or "US5781752"; click the patent title; then click "INPADOC patent family" to see that there are no foreign patents in the patent family). 
nonexclusively and that the firms they sued had commercialized the inventions without exclusivity, it is difficult to argue that these inventions would not have been brought to practical application if they had been in the public domain.

Our conclusion that federal grant recipients should seek patents only when exclusive rights are necessary for commercialization should be unsurprising to those who have closely followed the Bayh-Dole debates. Economic and legal scholars concur on this point. ${ }^{134}$ The $\mathrm{NIH}$ - one of the largest federal grant agencies-promulgated regulations instructing grant recipients that biomedical research tools and genomic inventions should be patented and exclusively licensed only when necessary for commercialization. ${ }^{135}$ (These regulations are not binding and are typically not followed, though they may have hortatory value. ${ }^{136}$ ) And over one hundred universities themselves have endorsed a (also non-binding) statement of licensing principles stating that universities "should strive to grant just those rights necessary to encourage development of the technology." 137

But to our knowledge, no one has yet proposed any systematic way to determine whether a given invention needs exclusive patents. The underlying problem is asymmetric information about the costs of commercialization. If policymakers had full information about these commercialization costs, there would be better policy tools than patents to ad-

\footnotetext{
1.34 See, e.g., Arti K. Rai \& Rebecca S. Eisenberg, Bayh-Dole Reform and the Progress of Biomedicine, LAW \& CONTEMP. PROBS. Winter/Spring 2003, at 289, 30001 (noting that nonexclusive licenses "impose[ ] a modest tax on product development" and function only "to generate revenue for the patent owner," which is not a goal of the Bayh-Dole Act); Bhaven N. Sampat, Patenting and US Academic Research in the 20th Century: The World Before and After Bayh-Dole, 35 RES. POL'Y 772,786 (2006) ("[F]rom a social welfare perspective . . . we would want universities to issue exclusive licenses on patented inventions only when non-exclusive licensing fails to promote use or commercialization.").

135 Best Practices for the Licensing of Genomic Inventions: Final Notice, 70 Fed. Reg. 18413 (Apr. 11, 2005); Principles and Guidelines for Recipients of NIH Research Grants and Contracts on Obtaining and Disseminating Biomedical Research Resources: Final Notice, 64 Fed. Reg. 72090 (Dec. 23, 1999).

136 Rai \& Eisenberg, supra note 134, at 293-94.

137 CAL. INST. OF TECH. ET AL., IN THE PUBLIC INTEREST: NINE POINTS TO CONSIDER IN LICENSING UNIVERSITY TECHNOLOGY 2 (2007), https://otl.stanford.edu/documents/ whitepaper-10.pdf [https://perma.cc/PX34-4BLW]. For a list of the over one hundred institutions that have signed the Nine Points, see Nine Points To Consider, ASS'N. OF UNIV. TECH. MANAGERS, http://www.autm.net/advocacy-topics/ government-issues/principles-and-guidelines/nine-points-to-consider-when-li censing-university [https://perma.cc/D2PR-BZTL].
} 
dress this market failure. ${ }^{138}$ As described in section III.A.2, the Bayh-Dole Act has a built-in tool to address some of the social costs of university patenting - march-in rights-but these have so far proved ineffective. ${ }^{139}$ What is needed is a mechanism to cause private parties to reveal their commercialization costsand we think that the market test we describe in Part II can satisfy this need.

II

THE SOlUtion: A MARKET TEST OF EXClUSIVITY FOR BAYH-DOLE PATENTS

In Part I, we argued that Bayh-Dole patents are currently justified only to the extent needed for commercialization. Here, we describe our proposal for a market test to determine whether exclusive rights are in fact needed for any given invention. In subpart II.A, we explain the basic idea behind the market test: by seeing whether firms will commit to commercializing federally funded inventions for less than the full exclusive patent term-such as under a free nonexclusive licenseuniversities can determine whether exclusivity is needed in a given case.

In subpart II.B, we introduce a formal model and demonstrate that in cases when no firm will commit to a commercialization under a free nonexclusive license, the university can still do better (from a social welfare perspective) than granting an exclusive license for the full patent term. The university can offer the inventions under an auction, but not a traditional auction to see which firm would pay the most for the licenserather, the metric of auction competition would be the exclusivity received by the firm. ${ }^{140}$ Our proposal is focused on only the minority of Bayh-Dole patents for which there are eager licen-

138 See Hemel \& Ouellette, Beyond the Patents-Prizes Debate, supra note 32, at 327-33 (discussing information asymmetries and government-set versus market-set innovation incentives).

139 See 42 U.S.C. \$ 203 (2012).

140 The possibility of changing the metric of auction competition to enhance social welfare has a long tradition. See, e.g., Barry E. Adler \& Ian Ayres, A Dilution Mechanism for Valuing Corporations in Bankruptcy, 111 YALE L.J. 83, 83 (2001); Ian Ayres \& Joel Waldfogel, A Market Test for Race Discrimination in Bail Setting, 46 STAN. L. REV. 987, 1037-38 (1994); Ian Ayres \& Barry Nalebuff, A Market Test for Credit Cards, Forbes (June 25, 2009, 10:00 PM), http://www.forbes.com/ forbes/2009/0713/opinions-market-credit-cards-why-not.html [http://perma. cc/E7UB-ESGF]. In the patent context, Michael Abramowicz has proposed using an exclusivity duration auction to encourage the commercialization of orphan drugs. Michael Abramowicz, Orphan Business Models: Toward a New Form of Intellectual Property, 124 HARv. L. REv. 1362, 1396-97 (2011). 
sees, ${ }^{141}$ and it thus would not change anything for patents that are currently unlicensed (or for which there is only one willing licensee), such as those involved in Penn State's recent auction of its unlicensed patents. ${ }^{142}$

One possible metric for our auction is years of exclusivity, though one can produce the same incentive by granting weaker rights over more years than stronger rights over fewer years, as one of us has illustrated. ${ }^{143}$ We thus show that deadweight loss is reduced by auctioning based on who will charge the smallest markup on the end product. We note, however, that this metric does not work well whenever there are many patents per product. We also consider the possibility of defensive commercialization by firms that want to avoid being the victim of the patent, and we reach the surprising conclusion that this kind of strategic bidding does not increase the cost to society.

\section{A. Basic Structure of the Market Test}

The basic idea underlying our proposal is that universities (and other institutions covered by the Bayh-Dole regime) should test the market to determine how federally funded inventions can be commercialized with the least cost to society. As we have explained, exclusivity is justified only when needed for commercialization, and nonexclusive licenses are generally against the public interest: inventions that firms are willing to commercialize without exclusivity should not have been patented at all. ${ }^{144}$

Under the simplest version of our market test, before granting an exclusive patent license, universities would be required to offer an invention under a nonexclusive license for a nominal fee. Alternatively, as a way to reduce the administrative costs of the market test and to ensure that the majority of university patents are unaffected, firms willing to commercialize without exclusivity should have the opportunity to object to a university's exclusive patent license within some

141 As noted above, as many as $95 \%$ of university patents are unlicensed. See supra note 104 and accompanying text. We are focused instead on the patents that are in the highest demand and which thus create the highest deadweight loss.

142 See Daniel R. Cahoy et al., The Role of Auctions in University Intellectual Property Transactions, 54 DUQUeSNe L. REV. 53, 54-55 (2016).

143 Ian Ayres \& Paul Klemperer, Limiting Patentees' Market Power Without Reducing Innovation Incentives: The Perverse Benefits of Uncertainty and NonInjunctive Remedies, 97 MicH. L. REv. 985, 1001-03 (1999).

144 See supra subpart I.A. 
timeframe. ${ }^{145}$ If a firm is willing to commit to commercializing the invention without exclusivity (with contractual provisions to ensure that the firm follows through on this commercialization commitment, discussed further in subpart II.C), then exclusivity is not warranted and the university would then be required to continue to license to all and any subsequent licensees for free. ${ }^{146}$

Alternatively, universities could be prohibited from charging even for the initial nonexclusive license, which would create a strong incentive against filing patents where exclusivity is unlikely to be needed for commercialization. It seems impractical, however, to have universities bear the risk of a patent turning out to be unnecessary, and there is value in having the universities disclose inventions early, including to preclude private firms from obtaining these unnecessary patents under first-to-file rules. It thus likely would be preferable to allow universities to charge a nominal fee for nonexclusive licenses with a reasonable revenue cap to cover the costs of obtaining and licensing the patent (plus the costs of obtaining other patents that never found a licensee).

But what if no firms will commit to commercialization for the free (or cheap) nonexclusive license? Does that mean that the university should grant an exclusive license for the full patent term in order to ensure commercialization? In the next section, we show that the answer is "no": universities could be required to use an auction to discover whether limited exclusivity was sufficient to induce commercialization. Of course, it may still be the case that there is only one willing commercializer, such as when the inventor's tacit knowledge is indispensable for commercialization. ${ }^{147}$ But our auction can be used to

145 This alternative might lead to the lowest administrative cost, given that our auction likely would not change the status quo for the vast majority of university patents. See supra note 141 and accompanying text.

146 We refer to "the invention" for simplicity, but a single disclosure may lead to many claims spread across a large patent family, with applicability in numerous fields of use. See Sandra L. Shotwell, Field-of-Use Licensing, in 2 INTELLECTUAL PROPERTY MANAGEMENT IN HEALTH AND AGRICULTURAL INNOVATION: A HANDBOOK OF BEST PRACTICES 1113 (Anatole Krattiger et al. eds., 2007), http://www.iphandbook.org/ handbook/resources/Publications/links/ipHandbook\%20Volume\%202.pdf [https://perma.cc/NFP9-RPS6]. In some cases, it may be appropriate to separately license different claims from the same family, or to separately license a single claim in different fields of use. For example, a new protein product could be licensed exclusively for development of a new therapeutic drug and nonexclusively for its use in other sectors. See id. at 1114 .

147 Such patents may be invalid for lack of enablement, however. Cf. Ouellette, Access to Bio-Knowledge, supra note 44, TIT 106-13 (explaining why inventions 
distinguish these cases from those in which commercialization is clearly possible at lower social cost.

\section{B. Modeling Bayh-Dole Patent Exclusivity Auctions}

Here, we analyze the probable outcome of a formal commercialization auction in which a bidder promises, if it wins the auction, to commercialize an invention in return for limited exclusivity rights. We abstract away from important questions of enforcement and timing discussed below. ${ }^{148}$ Instead, we focus here on how an auction can simultaneously reveal (1) whether granting exclusive patent rights is necessary and (2) what is the minimum grant of exclusivity necessary to incentivize commercialization.

Our proposed auction is analogous to a procurement auction in which the government puts out for bid items or services that it wishes to purchase and the seller with the lowest bid wins. In our setting, the bidders are selling commercialization services in exchange for limited exclusivity rights. For example, an auction in which bidders compete over the length of the exclusivity period would be won by the bidder who is willing to commercialize the invention for the fewest years of exclusive rights.

Note that the purpose of this exclusivity auction is not to identify the lowest bidder with the lowest commercialization cost: whoever wins will have a Coasean incentive to contract with the most efficient commercializer. Rather, the purpose is to harness knowledge of the lowest-cost commercializer (which may or may not reside with that party) in order to reduce the deadweight-loss distortion caused by unnecessary exclusivity. In many cases, the lowest-cost commercializer may be a startup that includes the university inventor, who will already have tacit knowledge that complements the patent. ${ }^{149}$

A central result of game-theory, called the "revenue equivalence theorem," establishes that a variety of auction mechanisms-including the English (ascending open outcry), Dutch (descending open outcry), Vickrey (second-price sealed), and first-price sealed auctions (where bidders account for the winner's curse)-will generate the outcome where the bidder with

that cannot be produced from the patent document alone may be invalid under 35 U.S.C. \& 112 (2012)).

148 See infra subpart III.B.

149 On the role of faculty inventors in technology transfer, see Peter Lee, Transcending the Tacit Dimension: Patents, Relationships, and Organizational Integration in Technology Transfer, 100 CALIF. L. REv. 1503, 1509, 1521-39 (2012). 
lowest reservation price will win the auction but in expectation only pay the second lowest bidder's value. ${ }^{150}$ For specificity and to choose an auction procedure in which the bidders' dominant strategy is simply to bid their reservation price, we assume that the commercialization auction is implemented with a Vickrey auction in which the bidder bidding the least patent protection wins, but receives the second-least protection bid. Thus, if the auction is based on years of exclusivity, and firms $\mathrm{A}, \mathrm{B}$, and $\mathrm{C}$ submit sealed bids stating that they would commercialize the invention in exchange for one, five, and ten years of exclusivity, respectively, then firm A would win the auction and would receive an exclusive license for five years-at which point $B$ and $C$ could enter the market under a free nonexclusive license.

\section{Limiting the Deadweight Loss of Incentivizing} Commercialization

To analyze the probable outcome of such a commercialization auction, imagine that there are $N$ bidders, each with costs of commercialization $C$, independently drawn from the following distribution:

$$
\begin{gathered}
p=\text { Probability that the ith bidder's } C_{i} \text { is } 0 \\
(1-p)=\text { Probability that the ith bidder's } C_{t} \text { is uniformly } \\
\text { distributed between } \$ 0 \text { and } \$ 100 .{ }^{151}
\end{gathered}
$$

This distribution captures the spirit of our analysis because it assumes that there is some discrete probability that a bidder can costlessly commercialize an invention, but also assumes that there is some probability that commercialization costs are positive and vary within some range.

To begin, we assume that bidders are not potential users of the invention and hence value any exclusive rights solely based on the invention's expected profits. For example, the invention might be a medical device that is only of value to end users and not as an input to any other industrial processes. We also assume that the price discrimination in licensing is not costeffective so that the rightsholder is limited to a single price-as

\footnotetext{
150 R. Preston McAfee \& John McMillan, Auctions and Bidding, 25 J. EcoN. LITERATURE 699, 710 (1987).

151 The assumption that the costs of commercialization are independently distributed in effect assumes that this is a private valuation auction (in contrast to common value auctions in which bidders' knowledge of their own value draw gives some additional information about other bidders' values). See Peter Cramton \& Alan Schwartz, Using Auction Theory to Inform Takeover Regulation, 7 J.L. ECON. \& ORG. 27, 28-29 (1991) (distinguishing between common value and independent private value auctions).
} 
is standard in many monopoly markup models. ${ }^{152}$ We relax these assumptions later.

As explained above, a bidder's dominant strategy in our auction is to bid her reserve price. With all bidders adopting this strategy, the bidder with the lowest reserve price will win the auction but be paid the second lowest bid. A non-consuming bidder's reserve price will be (epsilon above) the amount that produces expected profits equaling that bidder's cost of commercialization, $C_{i}$.

The expected outcome of any auction will thus turn on the second lowest commercialization cost among the bidders. Using ordered statistics, ${ }^{153}$ the expected commercialization cost of this pivotal bidder for a variety of possible numbers of bidders $(N)$ and probabilities $(p)$ of null commercialization costs is provided in Table 1:

TABLE 1. EXPECTED SECOND-LOWEST COMMERCIALIZATION COST FOR $N$ BIDDERS WITH $P$ PROBABILITY OF NULL

COMMERCIALIZATION COSTS.

\begin{tabular}{|c|cccccc|}
\hline & \multicolumn{7}{|c|}{$\mathbf{N}$} \\
$\boldsymbol{p}$ & $\mathbf{2}$ & $\mathbf{3}$ & $\mathbf{4}$ & $\mathbf{5}$ & $\mathbf{1 0}$ & $\mathbf{2 0}$ \\
\hline $\mathbf{1 0} \%$ & $\$ 60.00$ & $\$ 42.53$ & $\$ 32.08$ & $\$ 25.15$ & $\$ 9.86$ & $\$ 2.44$ \\
$\mathbf{2 0} \%$ & $\$ 53.33$ & $\$ 35.20$ & $\$ 24.58$ & $\$ 17.75$ & $\$ 4.39$ & $\$ 0.38$ \\
$\mathbf{3 0} \%$ & $\$ 46.67$ & $\$ 28.18$ & $\$ 17.84$ & $\$ 11.60$ & $\$ 1.61$ & $\$ 0.04$ \\
$\mathbf{4 0} \%$ & $\$ 40.00$ & $\$ 21.60$ & $\$ 12.10$ & $\$ 6.91$ & $\$ 0.48$ & $\$ 0.00$ \\
$\mathbf{5 0 \%}$ & $\$ 33.33$ & $\$ 15.63$ & $\$ 7.50$ & $\$ 3.65$ & $\$ 0.11$ & $\$ 0.00$ \\
$\mathbf{6 0 \%}$ & $\$ 26.67$ & $\$ 10.40$ & $\$ 4.10$ & $\$ 1.62$ & $\$ 0.02$ & $\$ 0.00$ \\
$\mathbf{7 0} \%$ & $\$ 20.00$ & $\$ 6.08$ & $\$ 1.84$ & $\$ 0.55$ & $\$ 0.00$ & $\$ 0.00$ \\
$\mathbf{8 0 \%}$ & $\$ 13.33$ & $\$ 2.80$ & $\$ 0.58$ & $\$ 0.12$ & $\$ 0.00$ & $\$ 0.00$ \\
$\mathbf{9 0 \%}$ & $\$ 6.67$ & $\$ 0.73$ & $\$ 0.08$ & $\$ 0.01$ & $\$ 0.00$ & $\$ 0.00$ \\
$\mathbf{1 0 0} \%$ & $\$ 0.00$ & $\$ 0.00$ & $\$ 0.00$ & $\$ 0.00$ & $\$ 0.00$ & $\$ 0.00$ \\
\hline
\end{tabular}

Thus, for example, if there are five bidders, and if each bidder has a $30 \%$ chance of no commercialization costs (and a $70 \%$ chance of commercialization costs uniformly distributed between $\$ 0$ and $\$ 100$ ), then the second lowest commercialization cost among the bidders is expected to be $\$ 11.60$. As one would expect, the expected cost decreases as $p$ or $N$ increases. The larger the number of bidders, the larger the chance that two will have low draws and the larger $p$, the larger

152 See, e.g., Ayres \& Klemperer, supra note 143, at 1013.

153 Expectations about "ordered statistics" can tell, inter alia, what is the expected lowest or second-lowest (or third-lowest, etc.) value when a discrete number of values are randomly drawn from some distribution. H. A. DAVID \& H. N. NAGARAJA, ORDER STATISTICS 9-22 (3d ed. 2003). 
the chance that at least two will have zero costs of commercialization. Indeed, the probability that at least two bidders will have null commercialization costs is provided in Table 2:

TABle 2. Probability of Two Bidders With NUll COMMERCIALIZATION COSTS.

\begin{tabular}{|c|c|c|c|c|c|c|}
\hline$p$ & 2 & 3 & $\begin{array}{l}N \\
4\end{array}$ & 5 & 10 & 20 \\
\hline $10 \%$ & $1.0 \%$ & $2.8 \%$ & $5.2 \%$ & $8.1 \%$ & $26.4 \%$ & $60.8 \%$ \\
\hline $20 \%$ & $4.0 \%$ & $10.4 \%$ & $18.1 \%$ & $26.3 \%$ & $62.4 \%$ & $93.1 \%$ \\
\hline $30 \%$ & $9.0 \%$ & $21.6 \%$ & $34.8 \%$ & $47.2 \%$ & $85.1 \%$ & $99.2 \%$ \\
\hline $40 \%$ & $16.0 \%$ & $35.2 \%$ & $52.5 \%$ & $66.3 \%$ & $95.4 \%$ & $99.9 \%$ \\
\hline $\mathbf{5 0} \%$ & $25.0 \%$ & $50.0 \%$ & $68.8 \%$ & $81.3 \%$ & $98.9 \%$ & $100.0 \%$ \\
\hline $60 \%$ & $36.0 \%$ & $64.8 \%$ & $82.1 \%$ & $91.3 \%$ & $99.8 \%$ & $100.0 \%$ \\
\hline $70 \%$ & $49.0 \%$ & $78.4 \%$ & $91.6 \%$ & $96.9 \%$ & $100.0 \%$ & $100.0 \%$ \\
\hline $80 \%$ & $64.0 \%$ & $89.6 \%$ & $97.3 \%$ & $99.3 \%$ & $100.0 \%$ & $100.0 \%$ \\
\hline $90 \%$ & $81.0 \%$ & $97.2 \%$ & $99.6 \%$ & $100.0 \%$ & $100.0 \%$ & $100.0 \%$ \\
\hline $100 \%$ & $100.0 \%$ & $100.0 \%$ & $100.0 \%$ & $100.0 \%$ & $100.0 \%$ & $100.0 \%$ \\
\hline
\end{tabular}

In our previous example, with five bidders and a $30 \%$ null cost probability, there is a $47.2 \%$ chance that at least two of the bidders will have zero commercialization costs. This possibility is particularly relevant to our analysis because it suggests that there are circumstances in which commercialization auctions will produce outcomes with very little or no patent protection.

Auctions can spur efficiency by allowing rights and duties to flow to the highest valuer. ${ }^{154}$ Commercialization auctions might accordingly enhance efficiency by allowing the lowest cost commercializer to win the right to commercialize. However, we do not emphasize this benefit in our analysis because university patentees already have incentives to find low-cost commercializers. We observe universities co-venturing with startups and established firms that are better suited to bring inventions to the market. Indeed, nothing would stop universities from holding their own procurement auction to discover the least-cost commercializer. Rather, we focus on how particular kinds of commercialization auctions can reduce the deadweight loss of rightsholding relative to the current monopoly pricing regime.

154 McAfee \& McMillan, supra note 150 , at 714 . 


\section{Competing over Duration or Revenue Caps}

One approach to limiting patent power would be to have the bidders-including the university-compete over the length of the exclusive license. Bidders with lower $C_{i}$ might be willing to take on the costs of commercialization for substantially fewer years of patent protection than the twenty years that universities currently are granted. (The effective life of a patent is of course twenty years minus the time in prosecution, but we will refer to twenty-year patents for simplicity. ${ }^{155}$ ) If bidders competed on license term by bidding the number of years ( $Y$ ) of exclusive patent protection for which they would be willing to take on the costs of commercialization, a bidder's reservation bid can be derived from the following equation:

$$
C_{i}=P m * Q_{m} * A(Y)=P_{m} * Q_{m} * \frac{1-(1+r)^{-Y}}{r}
$$

Equation 1 sets the one-time commercialization cost $C_{i}$ equal to the annuitized monopoly profits per period (where $P_{m}$ and $Q_{m}$ are respectively the expected monopoly price and quantity, and $A(Y)=(1-(1+r)-Y) / r$ is the annuitization rate which is an increasing function of the number of years $Y$ and a decreasing function of the annual interest rate r). ${ }^{156}$ Bidders with lower $C_{i}$ would be willing to commercialize for fewer years of patent protection, and bidders with no commercialization costs would, if forced by other bidders in an auction, be willing to commercialize for a license of zero duration.

Alternatively, one could imagine an auction that limited patent power, not by limiting the duration of the exclusive rights, but by capping the revenue that could be earned in any period. ${ }^{157}$ Under this regime, the rightsholder would gain an exclusion right for twenty years but would be bidding on a revenue amount lower than the monopoly revenue $\left(P_{m}^{*} Q_{m}\right)$ that it would be willing to receive in order to take on the commercialization obligation. ${ }^{158}$ (Such a structure would of course be challenging if the invention represents only a minor component

\footnotetext{
15535 U.S.C. $\$ 154(a)(2)(2012)$.

156 We assume that other than the commercialization costs, there are no marginal costs to licensing the patent.

157 These are not the only possibilities. For example, Michael Abramowicz has discussed how patents might be awarded through auctions to the party willing to sell an invention for the lowest price. See Michael Abramowicz, The Uneasy Case for Patent Races over Auctions, 60 STAN. L. REv. 803, 849-54 (2007).

158 This kind of auction might alternatively be structured so that bidders would compete on the basis of price per unit or on licensing profits instead of revenue. But administratively gross revenue is more readily observed for purposes of enforcement and produces identical results as price or profit auction in model described in the appendix.
} 
of a product to which revenue can be tied, so there might be few cases in which it is administratively feasible in practice. ${ }^{159}$ ) If bidders competed on the maximum periodic revenue over an invariant twenty-year rights period, a bidder's reservation (revenue) bid $\left(R_{B}\right)$ would be derived by:

$$
C_{i}=R_{B} * A(20)=R_{B} * \frac{1-(1+r)^{-20}}{r}
$$

Equation 2 is analogous to Equation 1 except that it sets the commercialization cost $C_{i}$ equal to the annuitized revenue cap per period. As with competition over the duration of exclusive rights, revenue competition among bidders with no commercialization costs would produce commercialization with zero (or epsilon) licensing revenue.

Either form of auction competition-over duration or over revenue-has the potential of reducing the deadweight loss associated with the current Bayh-Dole patent regime. But it turns out that the revenue cap auction produces less social (deadweight) loss than the duration auction.

To see this with a simple numeric example, ${ }^{160}$ imagine that the annual interest rate is $10 \%$ and that the annual demand for the invention is expected to remain constant over the next twenty years and can be described by the linear demand curve:

$$
P=200-Q
$$

We continue to assume that there are zero costs of licensing other than the fixed costs of commercialization, which we assume, for this example, are equal to $\$ 50,000$. It can be shown that an unrestrained patentee will charge a monopoly price of $\$ 100$ and produce annual revenues of $\$ 10,000$ with a twenty-year annuitized present value of $\$ 85,135$. With these prospective profits, the university will take on the cost of commercialization and earn in present value terms an expected profit of $\$ 35,135$. The problem with this outcome, however, is that in this equilibrium, consumer surplus is unduly restricted by the monopoly overcharge for the full twenty-year period.

The duration auction can mitigate this problem. The reservation bid (derived from Equation 1) of a bidder with commercialization cost of $\$ 50,000$ will be approximately 7.3 years. If there are at least two bidders with this commercialization cost, then consumers of the invention will only have to bear the monopoly overcharge for this shorter period and then can ex-

159 Even in the pharmaceutical industry, products often embody multiple distinct inventions. See Ouellette, How Many Patents Does It Take To Make a Drug?, supra note 30, at 314-315.

160 We analyze a more general (and interactive) linear model in the Appendix. 
pect to be able to consume the off-patent invention at the competitive price (assumed here to be zero). In this example, social welfare increases relative to the twenty-year monopoly by $22.6 \% .{ }^{161}$

The revenue cap auction, however, does an even better job of mitigating the monopoly overcharge problem. The reservation revenue cap bid (derived from Equation 2) of a bidder with a $\$ 50,000$ commercialization cost will be approximately $41.3 \%$ lower than the monopoly revenue charged by an unrestrained patentee. If there are at least two bidders with this cost, then they can be expected to reduce the cap to this limited revenue with an associated increase in consumer welfare. ${ }^{162}$ In this example, the revenue cap auction increases social welfare relative to the twenty-year monopoly by $47.8 \% .^{163}$

The revenue cap auction in this example improves social welfare substantially more than duration auction. ${ }^{164}$ Holding the rightsholder profits constant, consumers are better off being subjected to a restrained price for more years than to a monopoly price for fewer years. The intuition for the dominance of revenue cap bidding can be analogized to what economists call Ramsey pricing. ${ }^{165}$ To generate a certain amount of tax revenue, the tax structure that will minimize the distortion consumption effect (read: deadweight loss) will tend to tax as many goods as possible (so as to create small distortions in a

161 Social welfare is the sum of producer and consumer surplus. In the monopoly pricing equilibrium, the producer surplus has a present value (described above) of $\$ 35,135$, while the present value of consumer surplus can be derived in the Appendix to be $\$ 42,568$, for social welfare equal to $\$ 77,703$. In contrast, the duration auction competition reduces producer surplus to zero but expands the present value of consumer surplus (as can be derived in the Appendix) to $\$ 95,271$ (which is the present value of consumer surplus over the initial years of monopoly (\$100) pricing and the residual years of competitive (\$0) pricing). Thus, the duration auction in this example increases social welfare by $\$ 17,568$ or $22.6 \%$.

162 Instead of charging the monopoly price of $\$ 100$, a licensee limited to periodic revenue of $\$ 5,873$ would (as derived in the appendix) set a price of just $\$ 35.80$.

163 The revenue cap auction competition again reduces producer surplus to zero but expands the present value of consumer surplus (as shown in the appendix) to $\$ 114,828$ (which is the present value of consumer surplus over twenty years of restrained $(\mathrm{p}=35.8)$ pricing). Thus, the revenue cap auction in this example increases social welfare by $\$ 37,125$ or by $47.8 \%$.

164 The duration auction produced social welfare of $\$ 95,271$, while the revenue auction produce social welfare of $\$ 114,828$. This represents an improvement of approximately $20.5 \%$.

165 See Frank P. Ramsey, A Contribution to the Theory of Taxation, 37 Econ. J. 47, 54-58 (1927); see generally William J. Baumol, Ramsey Pricing, in 4 THE NEW PALGRAVE: A DictionaRY OF ECONOMICS 49, 49-51 (John Eatwell et al. eds., 1987) (reviewing the subsequent literature). 
broad variety of markets). ${ }^{166}$ If we view each year as a separate product, then the most efficient way-à la Ramsey-to produce revenues sufficient to cover the commercialization cost is to impose some tax on every product. We would not expect to tax only some of the products. But the duration auction violates the Ramsey intuition by taxing just the first $Y$ years and then imposing no "tax" on subsequent years. The revenue cap auction is likely to be more efficient than the duration auction because it better comports with the Ramsey intuition that smaller taxes on a broader tax base tend to be less distortionary. In the remaining sections, we focus on the revenue cap auction exclusively because of its efficiency advantage.

\section{Defensive Bidding by Consumers}

Until now, we have examined the bidding behavior of nonconsumers of the underlying invention. Non-consumers' sole value in winning a commercialization auction comes from the potential revenues conferred by the limited exclusivity grant from the government. Consumers of the underlying invention, however, have an additional rationale for bidding. By winning the auction, a consumer can avoid the distortionary effect of being subject to the exclusionary license of another rightsholder. Accordingly, it might be rational for consumer bidders to bid more aggressively than non-consumer bidders with similar commercialization costs.

To formalize this intuition, this Section begins by deriving the reservation bid in a revenue cap auction for a monopsonist bidder (who expects to be the only consumer of the invention)an assumption we relax later. A monopsonist's reservation bid can be derived from finding the bid at which its payoff from winning the auction is equal to its payoff from losing the auction. At this level, the monopsonist is indifferent between winning and losing the auction. A monopsonist's payoff from losing an auction with a revenue cap, $B$, is equal to its annuitized consumer surplus of being subject to a rightsholder constrained by the revenue cap. ${ }^{167}$ A monopsonist's payoff of winning the auction is the annuitized consumer surplus of licensing the invention to itself at a competitive (zero) price

\footnotetext{
166 This analysis of Ramsey pricing is taken from Ayres \& Klemperer, supra note 143 , at 991 .

167 A rightsholder constrained to earn a revenue amount strictly less than the monopoly revenue level can achieve this by charging a price higher than the monopoly level or a price lower than the monopoly level. We assume that the rightsholder will prefer to establish a larger presence in the downstream market and will accordingly choose the more socially efficient lower price.
} 
minus the costs of undertaking the commercialization. In algebraic terms, the monopsonist's reserve bid will hence be derived from:

$$
C S_{B}^{*} A(20)=C S_{C} * A(20)-C_{i}
$$

where $C S_{B}$ and $C S_{C}$ are, respectively, the consumer surplus for a particular bid, $B$, and for the competitive equilibrium and, as before, $A(20)$ is the twenty-year annuitization rate, and $C_{i}$ is the monopsonist's commercialization costs. Equation 3 can be rewritten as

$$
C S_{C}-C S_{B}=C_{i} / A(20)
$$

which has a graphic interpretation in Figure 1:

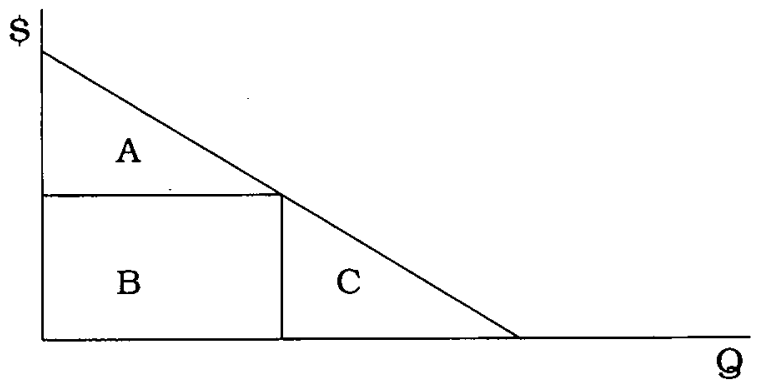

The left-hand side of Equation 4 represents the marginal increase in consumer welfare from winning the auction. Graphically, this benefit is equal to the areas of B and C. By bidding more aggressively-effectively committing to expand output - the monopsonist bidder can avoid the deadweight loss (area C) but only by agreeing to take on the costs of commercialization. Graphically, the monopsonist bidder will be indifferent between winning and losing the auction at the point at which areas $\mathrm{B}+\mathrm{C}$ equal the annuitized equivalent of its commercialization cost $\left(C_{i} / A(20)\right)$. In contrast, Equation 2 implies that a non-consuming bidder will only be willing to bid down to a point at which area $B$ (the periodic licensing revenues) equals the annuitized equivalent of its commercialization cost $\left(C_{i}\right)$ $A(20))$. Because for any given bid areas $B+C$ will always be greater than simply area $\mathrm{B}$, we can infer that a monopsonist will always be willing to outbid a non-consuming bidder with the same commercialization costs.

The willingness of monopsonist bidders to bid more aggressively than similarly situated non-consumers can also be seen in the foregoing example. While the non-consuming bidder with a commercialization cost of $\$ 50,000$ would be willing to accept an annual revenue cap as low as $\$ 5,873$ (associated with a licensing price of $\$ 35.80$ ), a monopsonist bidder with the 
same cost of commercialization would be willing to bid as low as $\$ 5,364$ (associated with a licensing price of just \$31.91).

Because of the monopsonist's willingness to bid more aggressively than non-consumers with similar costs, it is possible for monopsonists with higher costs of commercialization to win the auction. In the foregoing example, a monopsonist with any cost $C_{i}$ up to $\$ 55,443$ will outbid a non-consumer with a $\$ 50,000$ commercialization cost. From a social welfare perspective, the possibility that monopsonists with inefficiently high commercialization costs would take on the duty to commercialize is troubling. But a monopsonist winning the commercialization auction also produces an efficiency advantage of eliminating the deadweight distortion caused by licensing at a price above the (zero) competitive price. In our model, these two efficiency effects exactly offset each other-meaning that the auction winner will produce the lowest combination of deadweight and commercialization costs. This surprising result can be seen by considering again Figure 1. The monopsonist bids down to the point where areas $B$ and $C$ equal the annuitized value of the monopsonist's commercialization cost. In contrast, a non-consumer bids down to the point where just area $B$ equals the annuitized value of its commercialization cost. But the non-consumer's overcharge produces deadweight loss equal to area $\mathrm{C}$. So for either type of bidder the combination of areas $\mathrm{B}$ and $\mathrm{C}$ is equal to the combination of its annuitized commercialization cost plus the periodic deadweight loss of any subsequent overpricing.

Thus, happily, the bidder with lowest reservation bid can be expected to be in aggregate the most efficient commercializer/price-setter. A monopsonist with higher commercialization costs will only be able to outbid a non-consumer if its social welfare advantage in pricing outweighs its disadvantage in commercialization.

Of course, monopsony is relatively rare. ${ }^{168}$ It is natural therefore to consider the bidding behavior of consumers who have only a share $\left(s_{t}<1\right)$ of the assumed invention demand at any particular price. For such a consumer, Equation 4 can be generalized by assessing the bidder's payoff from just winning or just losing the auction. If the bidder just loses the auction (because her reservation bid is epsilon above the winning bid),

168 We do not assume that the monopsonist consumer of the invention is in turn a monopolist in the downstream market as there may be other means of producing the downstream product or services that do not require practicing the invention in question. 
her payoff is $s_{i}^{*} A(20) * C S_{B}$, which equals the present value of the stream of her share of consumer surplus. If the bidder just wins the auction (because her reservation bid is epsilon below the second place bid), her payoff is $A(20) *\left(1-s_{i}\right) * R_{B}+s_{i}{ }^{*}$ $A(20) * C S_{c}-C_{i}$, which equals the present value of the revenue the bidder can make from licensing the invention to the other invention consumers plus the present value of the bidder's own consumer surplus of being able to purchase the invention at a competitive (zero) price minus the costs of commercialization. Thus, as above, the bidder's reservation price can be derived from the equation:

$s_{i}^{*} A(20) * C S_{B}=A(20) *\left(1-s_{i}\right) * R_{B}+s_{i}^{*} A(20) * C S_{c}-C_{i}$

Equation 5 nicely nests Equations 2 and 3 . When $s=0$, Equation 5 simplifies to Equation $2, A(20) * R_{B}=C_{i}$, the nonconsumer's reservation bid equation. And when $s=1$, Equation 5 simplifies to Equation $3, A(20){ }^{*} C S_{B}=A(20) * C S_{C}-C_{i}$, the monopsony reservation bid equation.

In the Appendix, we derive a closed-form solution for the reservation bid implied by Equation 5 . But here Table 3 instead shows how in our foregoing numeric example, key outcomes change as a bidder's share of the downstream market varies:

TABle 3. EFFect of Changing BidDER'S SHARE of DOWNSTREAM MARKET.

\begin{tabular}{|c|c|c|c|c|c|c|}
\hline & $0 \%$ & $20 \%$ & $40 \%$ & $60 \%$ & $80 \%$ & $100 \%$ \\
\hline \multirow{5}{*}{$\begin{array}{l}\text { Reserve Bid } \\
\mathbf{P}_{\mathbf{m}} \\
\mathbf{Q}_{\mathbf{m}} \\
\text { PV(CS) } \\
\% \text { Patent } \\
\text { DWL Eliminated }\end{array}$} & $\$ 5,873$ & $\$ 5,752$ & $\$ 5,642$ & $\$ 5,542$ & $\$ 5,449$ & $\$ 5,364$ \\
\hline & $\$ 36$ & $\$ 35$ & $\$ 34$ & $\$ 33$ & $\$ 33$ & $\$ 32$ \\
\hline & 164 & 165 & 166 & 167 & 167 & 168 \\
\hline & \multicolumn{3}{|c|}{$\$ 114,828 \$ 116,142$} & 118,391 & 119,370 & 120,271 \\
\hline & $56.6 \%$ & $57.6 \%$ & $58.5 \%$ & $59.4 \%$ & $60.1 \%$ & $60.8 \%$ \\
\hline
\end{tabular}

As expected from nesting, the reserve bid varies from the non-consumer's reservation of $\$ 5873$ when $s=0$ to the monoposonist's reserve of $\$ 5364$ when $s=1$. Moreover, following the logic of defensive bidding discussed above, the Table shows that the larger the bidder's share of the downstream market, the more aggressively she is willing to bid, and the larger the proportion of the deadweight loss of monopoly that is eliminated. Our earlier argument-that the lowest bidder will produce the lowest combination of commercialization and deadweight loss-also extends to the more general case of bidders with intermediate market shares. 
The nesting reservation bid Equation 5 can be rewritten in terms of the areas depicted in Figure 1 to be:

$$
\begin{gathered}
\left(1-s_{l} * R_{B}+s_{i}^{*} C S_{C}-s_{l}^{*} C S_{B}=C_{l} / A(20)\right. \\
\left(1-s_{l}\right) *\left(\text { Area B) }+s_{i}{ }^{*}(\text { Area A }+B+C)-s_{l}^{*} \text { (Area A) }=C_{i} / A(20)\right. \\
\text { (Area B) }+s^{*}\left(\text { Area C) }=C_{l} /\right. \text { a(20) }
\end{gathered}
$$

Intuitively, the bidder is willing to bid down until the annuitized marginal cost of winning the auction, $C_{i} / A(20)$, is equal to the marginal benefit (which is equal to its benefit from avoiding the licensing, $s *$ (Areas $\mathrm{B}+\mathrm{C}$ ), plus its benefit from selling to other consumers, $(1-s){ }^{*}$ (Area B). But at this reservation price, the bidder would be producing deadweight loss of $(1-s) *$ (Area $C$ ). Once again at the reservation price, the combined deadweight and commercialization costs will be equal to Area B + C. So for bidders with any share, the winner of the auction may not be expected to minimize the costs of commercialization or might not minimize the deadweight loss of patent overpricing, but happily can be expected to minimize the combination of these two costs.

Since in many cases efficient commercialization can be accomplished by separately contracting with the lowest cost commercializer, our analysis suggests that invention consumers with larger market shares would have a structural advantage in commercialization auctions because of their willingness to bid more aggressively to "defensively" avoid the deadweight loss of patent overcharges.

The larger the bidder's market share, the more winning eliminates the overcharge deadweight loss. The social welfare advantage of the monopsonist bidder described above might be emulated in a legal regime that allowed consumers to collude in their bidding strategy. A consumer cooperative might be willing to emulate the benefits of a monopsonist-eliminating all deadweight loss. But one might also imagine examples in which collusion among consumer bidders suppressed competition and thereby decreased social welfare. For example, imagine a world in which the university and all other non-producers have relatively high commercialization costs and that without collusion two producers each with $10 \%$ shares and extremely low commercialization costs would bid the revenue cap down to virtually nothing. In such circumstances, we might worry that collusion by the low cost bidders would not lead them to bid more aggressively but instead suppress bidding competition so that they could overcharge the remainder of the downstream market. 
Stepping back, our modeling exercise has produced the following takeaways:

1. A commercialization auction can produce zero exclusivity outcomes and more generally reveal to government the amount of exclusivity needed to induce commercialization.

2. Revenue cap bidding (or price cap bidding) is more efficient than duration bidding, though often less administratively feasible.

3. Defensive bidding by consumers will be more aggressive than by non-consumers with equal commercialization costs.

4. The winning bidder will tend to give rise to the lowest combined commercialization and deadweight costs.

5. Bidder collusion by consumers is good if it tends to reduce deadweight loss (and lead to more aggressive bidding), but it is bad if it takes away potential competitors (and leads to less aggressive bidding).

Richard Posner long ago argued that auction-like competition for legally created market power would tend to transform monopoly profits into additional deadweight losses. ${ }^{169}$ In Posner's model, the inefficiency of acquiring the governmentsponsored monopoly increased to the deadweight loss of Area B as well as the traditional deadweight loss triangle (Area C). ${ }^{170}$ Our strikingly happier result stems from changing the basis of competition. Instead of competing over the most lavish lobbying expenses, bidders in our model compete by committing to commercialize effectively a lower compulsory license fee.

III

\section{IMPLEMENTING THE MARKET TEST}

For readers who are now convinced that a market test for Bayh-Dole patents is a good idea-or is at least worth trying until more evidence is developed-the next question is: how do we make it happen? In subpart III.A, we explore the possible courses for three different actors in the current system: universities, federal grant agencies, and Congress. A well-motivated member within any one of them could make progress toward using the market test to enhance social welfare. Subpart III.B

169 See Richard A. Posner, The Social Costs of Monopoly and Regulation, $83 \mathrm{~J}$. POL. ECON. 807, 809-811 (1975).

170 See id. 
then discusses some details of implementation and possibilities to avoid gaming.

\section{A. Institutional Actors}

\section{Universities}

Some universities might be inspired to implement the market test on their own or might be spurred to do so by student groups and other constituents focused on access to university technologies. A number of scholars have urged universities to focus on the public interest when designing their patenting and licensing policies. ${ }^{171}$

One might be skeptical that any university would take this step, especially given the stories of increasing litigiousness and focus on monetization described in the Introduction. ${ }^{172}$ But there have been noteworthy instances in which universities have used their patent rights for social good rather than maximizing profit, including at Yale:

[I]n 1990 Yale patented the use of the drug stavudine (d4T) to treat HIV and granted an exclusive license to Bristol-Myers Squibb. Under the trade name Zerit, stavudine became a key drug for treating HIV. With a cost of over $\$ 1600$ per year, however, it was inaccessible to most patients in developing countries. Médecins Sans Frontières (MSF) wanted to distribute stavudine in South Africa. An Indian manufacturer offered to supply the drug for $\$ 40$ per year, but MSF was unable to accept because Yale had patented stavudine in South Africa. With the help of Yale Law students Amy Kapczynski (now a law professor) and Marco Simons, MSF approached Yale, which began negotiating with Bristol-Myers Squibb. After the issue was publicized in the New York Times, Bristol-Myers Squibb announced that it would not enforce the stavudine patent in South Africa and that it would sell Zerit in sub-Saharan Africa for \$55 per year. ${ }^{173}$

171 See, e.g., Amy Kapczynski et al., Addressing Global Health Inequities: An Open Licensing Approach for University Innovations, 20 BERKELEY TECH. L.J. 1031, 1078-90 (2005); Lemley, Are Universities Patent Trolls?, supra note 9, at 625-28; Ouellette, Addressing the Green Patent Global Deadlock, supra note 6, at 1735; Ouellette, How Many Patents Does It Take To Make a Drug?, supra note 30, at 321-22.

172 See supra notes 6-24 and accompanying text; see also Jay P. Kesan, Transferring Innovation, 77 FORDHAM L. REV. 2169, 2207 (2009) ("University tech transfer activities continue to be predominantly patent-centric and revenue driven with a single-minded focus on licensing income and reimbursement for legal expenses.").

173 Ouellette, How Many Patents Does It Take To Make a Drug?, supra note 30, at 309 (footnotes omitted). 
This campaign led to the establishment of the activist group Universities Allied for Essential Medicines (UAEM), which has pushed universities to consider how their patent policies affect global health, and which helped craft-and convince universities to sign-two licensing policy statements related to the dissemination of medical technologies. ${ }^{174}$ UAEM now issues an annual report card that grades universities on their global health impact in an effort to increase transparency about university policies. ${ }^{175}$ In the 2015 version, Johns Hopkins topped the list with an overall $\mathrm{A}$-, our institutions-Yale and Stanford-received a B and a B-, and grades ran all the way down to $F$ (earned by Wake Forest University and the University of Cincinnati). 176

These student campaigns have focused on access to pharmaceuticals in in low-income countries-an industry in which, as we have explained, having at least some exclusive patent rights is important for commercialization. ${ }^{177}$ The case for reduced reliance on exclusive rights or costly nonexclusive licenses is even stronger for inventions that would be commercialized even if they were not patented, and access-focused student groups might consider turning their attention to university patents on non-pharmaceutical inventions.

The negative publicity universities have received about behaving like "patent trolls" might actually make it easier to change their behavior. ${ }^{178}$ If a few prominent universities implement some version of our market test and show it is feasible, it could encourage others or spur legislation making this policy

174 See id. at 309-11 (describing the 2007 "Nine Points" statement, CAL. INST. OF TECH. ET AL., supra note 137, and Ass'N OF UNIV. TECH. MANAGERS ET AL., STATEMENT of PRinciples and Strategies fOR the Eguitable Dissemination of MEdical TECHNOLOGIES (2009), http://otd.harvard.edu/upload/files/Global_Access_State ment_of_Principles.pdf [https://perma.cc/2CTA-9L6X]).

175 Donald G. McNeil Jr., University Grades Are Mixed on Research for the Poor, N.Y. TIMES, May 12, 2015, at D3, http://www.nytimes.com/2015/05/12/ health/university-grades-are-mixed-on-research-for-the-poor.html [https:// perma.cc/7GCY-NQAB].

176 University Report Card: Global Equity \& Biomedical Research, UNIV. ALLIED FOR ESSENTIAL MED., http://globalhealthgrades.org [https://perma.cc/LB48VEKB]. There are separate subgrades focused on "access," which may be a better metric for those interested in patent policies. UAEM might consider adding points to the grade of a university that implements of a policy of patenting and licensing inventions under the conditions described in this article.

177 See supra notes 28-29 and accompanying text.

$178 C f$. Lemley, Are Universities Patent Trolls?, supra note 9, at 611-12 (explaining how universities are increasingly viewed as patent trolls, and arguing that they "should take a broader view of their role in technology transfer" rather than engaging in the "bad acts" that "concern[] us about trolls"). 
mandatory. ${ }^{179}$ Ideally, universities that test the market test should do so on a randomized basis and should develop nonpatent-related metrics to track the extent to which inventions that are not patented are commercialized. ${ }^{180}$

A university that chose to unilaterally implement the market test would not run afoul of the Bayh-Dole Act. Bayh-Dole gives universities the right but not the obligation to patent federally funded inventions. ${ }^{181}$ Universities must disclose federally funded inventions to the agency "within a reasonable time" and must decide whether to patent the invention "within two years after disclosure," though this time may be lengthened by the agency or shortened if a publication or other public disclosure imposes a closer deadline on when the invention may be patented. ${ }^{182}$ In practice, even these minimal requirements are not strictly followed, with many patents arising from federal funding neither being disclosed to the agency nor containing required government-interest statements. ${ }^{183}$

If a university elects not to patent an invention, the agency has the right to take title. ${ }^{184}$ But if the university made this choice because it showed that exclusivity is unnecessary for commercialization, it seems unlikely to us that the agency would intervene.

If a university elects to patent an invention, the Bayh-Dole Act does not require the university use any particular licensing structure. The patent can be licensed exclusively or nonexclusively; for free or for a hefty fee. The only obligation is that if the patent is licensed exclusively, the invention should be manufactured "substantially in the United States," if possible. ${ }^{185}$ Our market test is certainly permissible under the statutory requirements. As discussed below, if the university does not take "effective steps to achieve practical application of the subject invention," the agency may intervene to issue additional

179 One structural mechanism for this private ordering might be the coordinated patent pledges described in Jorge L. Contreras, Patent Pledges, 47 ARIZ. ST. L.J. 543, 567-69 (2015).

180 See generally Michael Abramowicz, Ian Ayres, \& Yair Listokin, Randomizing Law, 159 U. PA. L. REv. 929 (2011) (advocating greater use of randomized policy testing); Ouellette, Patent Experimentalism, supra note 36, 87-104 (describing the benefits of policy randomization in the patent context).

18135 U.S.C. $\$ 202$ (2012).

18235 U.S.C. $\$ 202(\mathrm{c})(1)-(2)$. The standard patent rights clauses appear at 37 C.F.R. $\$ 401.14$.

183 See Arti K. Rai \& Bhaven N. Sampat; Accountability in Patenting of Federally Funded Research, 30 NATURE BIOTECHNOLOGY 953, 954-55 (2012). But "universities are improving their compliance with reporting obligations." Id. at 955.

18435 U.S.C. § 202 (c)(2).

18535 U.S.C. $\$ 204$. 
licenses. ${ }^{186}$ But the market test is specifically designed to achieve practical application in the most efficient manner.

\section{Grant Agencies}

The agencies responsible for the largest amount of public research funding are Health and Human Services (50\%, primarily distributed through the $\mathrm{NIH}$ ), the Department of Energy $(12 \%)$, the Department of Defense (10\%), the National Aeronautics and Space Administration (NASA) (9\%), and the National Science Foundation (NSF) (8\%). ${ }^{187}$ These agencies could play a significant role in implementing the Bayh-Dole Act in a manner more closely aligned with its statutory goals.

As noted in the Introduction, federal agencies already have statutory authority to limit the patent rights of grant recipients. There are two key statutory hooks. First, under $\S 202$ of the Bayh-Dole Act, a funding agreement may limit a grant recipient's ability to patent "in exceptional circumstances when it is determined by the agency that restriction or elimination of the right to retain title to any subject invention will better promote the policy and objectives of this chapter ...."188 Recall that the Act begins by noting that "[i]t is the policy and objective of the Congress to use the patent system to promote the utilization of inventions arising from federally supported research or development . . . ."189 Using the market test to determine those circumstances in which utilization of federally funded inventions would be increased through less exclusivity would seem to fall squarely within this goal and would provide an objective means of determining whether the circumstances are such that an "exception" to the Bayh-Dole right to patent should be made. Under $\$ 202$, agencies funding non-pharmaceutical research might routinely include in funding agreements provisions requiring grantees to conduct an exclusivity auction in the exceptional circumstances that an interested third-party licensee objects to a proposed exclusive license and triggers the market-test mechanism. 190

The second statutory provision that allows agencies to limit university patent rights is $\S 203$, which states that when a grant recipient has already patented an invention, agencies

18635 U.S.C. § $203(\mathrm{a})(1)$.

187 NAT'L SCI. FOUND., supra note 1, at 4-86.

18835 U.S.C. $\$ 202(a)(i i)$.

18935 U.S.C. $\$ 200$.

190 See supra note 145 and accompanying text. 
may sometimes exercise "march-in rights."191 Specifically, the Act permits agencies "to require the contractor . . . to grant a nonexclusive, partially exclusive, or exclusive license in any field of use . . . upon terms that are reasonable under the circumstances," or "to grant such a license itself," if the agency determines that any one of several conditions are satisfied. ${ }^{192}$ For example, agencies can compel licensing if the contractor "has not taken, or is not expected to take within a reasonable time, effective steps to achieve practical application of the subject invention," 193 where "practical application" is defined as manufacture or practice under conditions such that the invention's "benefits are ... available to the public on reasonable terms." 194 Agencies can also exercise march-in rights where "necessary to alleviate health or safety needs." 195 March-in rights may also be used when "necessary to meet requirements for public use specified by Federal regulations." 196

There have been only five publicized petitions for agencies to exercise their march-in rights, all filed with the NIH, and in each case the NIH dismissed the petition without progressing to the march-in proceeding stage. ${ }^{197}$ The regulations governing march-in proceedings have thus never been used, much less tested in court. 198 While we favor ex ante application of the market test via $\S 202$, an agency could use its $\S 203$ march-in authority to implement a version of our market test. If a federally funded invention is patented and licensed in a way that threatens substantial constraints on quantity, an agency could exercise its march-in rights if the university failed to show with market-test evidence that exclusivity was necessary to promote the commercialization goals of the Bayh-Dole Act. A university that failed to undertake such a test would run the risk of failing this ex post inquiry. Without such evidence, an agency could reasonably conclude that the invention is not "available to the public on reasonable terms." 199

\footnotetext{
19135 U.S.C. § 203.

19235 U.S.C. $\$ 203(a)$.

19335 U.S.C. § $203(a)(1)$.

19435 U.S.C. $\$ 201(\mathrm{f})$

19535 U.S.C. \$ 203(a)(2).

19635 U.S.C. \& 203(a)(3).

197 See Whalen, supra note 27, at 1099-1106. For the NIH responses, see Policies \& Reports, NAT'L INSTS. HEALTH, http://www.ott.nih.gov/policies-reports [https://perma.cc/596G-AM5Z].

198 See 37 C.F.R. \$ 401.6 (march-in regulations); see also 35 U.S.C. \$ 203(a) (stating that march-in rights shall be used "in accordance with such procedures as are provided in regulations promulgated hereunder").

19935 U.S.C. $\S 201(f)$.
} 
It might seem unlikely that agencies that have never exercised march-in rights will now decide to do so, but if some universities continue to exercise their patent rights in ways that are hard to square with the public interest, ${ }^{200}$ agencies might find it more politically palatable to step in. ${ }^{201}$ Furthermore, some of the reluctance to use ex post march-in rights after a license is negotiated may stem from concerns about upsetting the licensee's reliance interests, which would not be a concern with our market test. Indeed, because some of the benefit from the market test is concentrated with private parties-those who would want to trigger exclusivity auctions to prevent competitors from receiving exclusive licenses-publicchoice theory suggests it should be more likely to be implemented than march-in rights, for which the benefits are more broadly distributed among the public.

A third way agencies could promote use of the market test is through their ex ante control over which projects get funded in the first place. ${ }^{202}$ Just as agencies like the NSF require universities to have conflict-of-interest policies, ${ }^{203}$ they could require universities to have socially responsible licensing policies that include a market test requirement. The NSF created its conflict-of-interest policies (as well as many other policies governing its grant awards) under its broad statutory authority "to prescribe such rules and regulations as it deems necessary governing the manner of its operations . . . "204

Alternatively, agencies could include patenting and licensing considerations in individual project reviews. For example, the NSF reviews projects not just for intellectual merit but also for "broader impacts," i.e., "the potential to benefit society,"205 which includes dissemination-the NSF "encourages grantees to share software and inventions ... and otherwise to make the

200 See supra notes 7-14 and accompanying text.

201 See, for example, the recent letter from over fifty congressmen urging the $\mathrm{NIH}$ to exercise its march-in rights. Letter from Lloyd Doggett et al., supra note 29.

202 This idea was first proposed by Ouellette, Addressing the Green Patent Global Deadlock, supra note 6, at 1736-37.

203 See NaT'L Sci. Found., PRoposal and AWard Policies and Procedures Guide IV-1 (2016), http://www.nsf.gov/pubs/policydocs/pappguide/nsf16001?/ nsf16_1.pdf [https://perma.cc/56PG-ZCG6]. This requirement for conflict-of-interest policies became effective in 1995 after a notice-and-comment period. 59 Fed. Reg. 33308 (June 28, 1994).

20442 U.S.C. $\$ 1870$ (a) (2012). For other grant policies, see NAT’L SCI. FOUND., supra note 203, at I-1 (referring to policies falling within the authority of $\S 1870$ ). 205 NAT'L SCI. FOUND., supra note 203, at III-2. 
innovations . . . widely useful and useable."206 If the NSF makes clear that commitment to use a market test to disseminate the invention is a positive factor under "broader impacts" review, it would bring patent and licensing concerns to the attention of the researchers applying for grants and not just university administrators.

Finally, federal agencies could help with some of the practical details of implementing and advertising patent auctions. A centralized website listing new university patents and auction information-perhaps run by a grant agency or by the Patent and Trademark Office (PTO)-would help spread information about available technologies to prospective commercializers. Bayh-Dole patents are already required to contain "a statement specifying that the invention was made with Government support and that the Government has certain rights in the invention."207 Compiling these patents in a single database would be quite straightforward; even better would be a requirement that universities update the database with information about pending applications and ongoing auctions. We return to these practical details in subpart III.B.

\section{Congress}

As explained in the prior two sections, implementing our market test proposal does not require legislative change: either universities or federal grant agencies could accomplish the main goals. But a Bayh-Dole amendment would make such a change easier and more uniform.

Most simply, it would be helpful if the statute explicitly stated that federally funded research should be exclusively licensed only when necessary for commercialization and can never be nonexclusively licensed for more than the cost of patenting, and leaving the details of implementation to agencies. Congress might also explicitly direct an agency to implement a randomized test of the market test and to study the resulting commercialization outcomes. ${ }^{208}$

206 NAT'L SCI. FOUND., MERTT REVIEW BROADER IMPACTS CRITERION: REPRESENTATIVE ACTIVITIES (2002), http://www.nsf.gov/pubs/2002/nsf022/bicexamples.pdf [https://perma.cc/B97V-S5T8].

20735 U.S.C. $\$ 202$ (c)(6) (2012). As noted, this requirement is not always followed, but compliance is improving. See supra note 183 and accompanying text. The PTO might improve compliance by affirmatively asking university applicants whether an invention stems from federal funds.

208 See supra note 180 and accompanying text. 
To be sure, given the success of the university lobby in legislative debates over patent reform, ${ }^{209}$ such a change may seem unlikely. But perhaps if universities continue to be viewed increasingly as patent trolls rather than as good actors in the system, ${ }^{210}$ there will be more momentum for reform.

\section{B. Timing, Enforcement, and Gaming}

Thus far, we've explained that at least three independent institutional actors-universities, federal grant agencies, and Congress-could implement the market test. But how should they implement it, and how might they prevent other actors who are less enthusiastic about the idea from undermining the system?

First, potential commercializers should be able to find out about new university technologies as quickly as possible. In the case of high-profile technologies such as CRISPR, ${ }^{211}$ the relevant firms will likely hear about the inventions from scientific publications and conferences. But a more general database of new inventions would aid this dissemination process and reduce search costs. The eighteen-month delay before patent applications are published makes little sense for university research, which scientists are eager to publish anyway. ${ }^{212}$ Bayh-Dole patent applications should be published in a central database at the time of filing. ${ }^{213}$

The exclusivity auction could begin at this time-perhaps in response to a trigger from an interested licensee ${ }^{214}$-and could run while the application is being prosecuted at the PTO. This process typically takes many months: over the past decade, the median patent has spent thirty to forty months in prosecution. $^{215}$ Prospective commercializers would enter the auction by submitting bids with the minimum amount of ex-

209 For example, the America Invents Act specified that a university is a "micro entity" entitled to reduced filing fees. 35 U.S.C. § 123(d); see also Andrew Ramonas, University Lobby Push, NAT'L L.J. (Apr. 7, 2014), http://www.nationallaw journal.com/id=1202649803262/University-Lobby-Push [https://perma.cc/ U64J-U236] ("More than three dozen universities are spending millions of dollars on Washington lobbyists to help shape patent litigation reform . . . .").

210 See supra notes 8-15 and accompanying text.

211 See supra notes 33-35 and accompanying text.

212 See Ouellette, Do Patents Disclose Useful Information?, supra note 88, at $582-83$.

213 As noted previously, such a database could be administered by the PTO or by a federal grant agency. See supra section III.A.2.

214 See supra note 145 and accompanying text.

215 See Dennis Crouch, Median Patent Prosecution Pendency, PATENTLY-O (June 15, 2015), http://patentlyo.com/patent/2015/06/patent-prosecution-pen dency.html [https://perma.cc/DTTQ-PVR9]. 
clusivity for which they would commercialize the invention, along with sufficient details to convince a reasonable observer of the firm's likelihood of success. For example, in a duration auction, bids would be the fewest years (or months) of exclusivity for which the firm would commercialize. If the auction is run as a Vickrey auction, as discussed above, bidders would submit sealed bids, and the winning firm-the one bidding the smallest amount of exclusivity-would pay the second-lowest bid. ${ }^{216}$ If only one firm is willing to commercialize, it could have an exclusive license for the full remaining patent term.

We do not know the optimal length of the auction period, and it likely varies by technological field. For some inventions with numerous applications, it may also be worth conducting separate auctions in different fields, just as universities currently offer field-specific patent licenses. Agencies regulating how the market test will be implemented may wish to experiment with different time periods, ideally using randomized trials. ${ }^{217}$

The requirement to publish inventions and to initiate the market test at the time of filing a patent application could be required either by statute or as part of agency-funding agreements. Universities could also be required to stop pursuing the patent if there is rapid commercialization without exclusivity. A condition of issuing a Bayh-Dole patent could be an affirmation from the applicant that the invention has not already been put into practical application. If universities seem reluctant to implement these patenting and licensing practices, tying evidence of cooperation with such requirements to future grant funding would provide a strong incentive. ${ }^{218}$

To ensure that the winner of a market test in fact commercializes the invention in good faith, the licenses can use due diligence milestones, which are already common in patent commercialization contracts to "ensur[e] that . . . licensees will develop and market the licensed products in a timely manner" and "will not sit on the licensed technology, for example, for

\footnotetext{
216 See supra note 150 and accompany ing text.

217 See supra note 180 and accompanying text.

218 There are numerous ways in which reluctant universities might engage in strategic behavior to maximize their own returns, but this might not be worse than the status quo. For example, if universities strategically file narrower patents that they are more likely to be able to exclusively license, then this still would be an improvement: these exclusive licenses would create less deadweight loss than exclusive licenses on broader patents would.
} 
defensive purposes." 219 The intended outcome could be based on the current statutory language of the Bayh-Dole Act for achieving "practical application of the subject invention":220

The term "practical application" means to manufacture in the case of a composition or product, to practice in the case of a process or method, or to operate in the case of a machine or system; and, in each case, under such conditions as to establish that the invention is being utilized and that its benefits are to the extent permitted by law or Government regulations available to the public on reasonable terms. ${ }^{221}$

The duty to exercise diligence in commercializing could be based on a legal standard similar to whether you exercised reasonable diligence in reducing an invention to practice. ${ }^{222}$ Initial commercializers who fail on their promise to commercialize could be made to pay expectation damages to the patentee, and the patentee could be allowed to re-auction the invention if commercialization benchmarks are not met. Evidence of egregious bad faith might subject initial licensees to more significant penalties. ${ }^{223}$

Even with these diligence requirements, one might be concerned that commercialization is not a binary option: even if a firm will commercialize a Bayh-Dole patent in good faith and make the invention available to the public on reasonable terms, it is possible that a firm with greater exclusivity may have somehow commercialized the invention better, such as by introducing a product with higher quality or by commercializing it faster. ${ }^{224}$ Of course, these benefits must be weighed against

219 Theodore A. Wood, Launching Patent Licensing for an Emerging Company, 30 U. DAYTON L. REv. 265, 270 (2004). Ted Sichelman discusses the related problem of ensuring that recipients of his proposed "commercialization patent" actually commercialize the invention, but note that he is focused on inventions that no one wants to commercialize in the current system, whereas we are focused on inventions that many firms want to commercialize. Sichelman, supra note 69, at $402-11$.

22035 U.S.C. \& 203(a)(1) (2012).

22135 U.S.C. § 201 (f).

222 See generally Brown v. Barbacid, 436 F.3d 1376, 1378-82 (Fed. Cir. 2006) (reviewing the reasonable diligence standard).

223 But enlightened tests of due diligence would need to balance the risk that penalties would have an ex ante chilling effect on the willingness of potential licensees to take on the duty of commercializing the invention. Initial licensees can only profit from a license if they are able to bring the product to market. For an overview of the tradeoffs between specifying contractual provisions at the time of contracting versus during later litigation, see generally Robert E. Scott \& George G. Triantis, Anticipating Litigation in Contract Design, 115 YALE L.J. 814 (2006).

$224 C f$. Michael Risch, Licensing Acquired Patents, 21 GEO. MASON L. REv. 979, 1009-12 (2014) (arguing that licensing can lead to earlier commercialization). 
the associated deadweight loss costs-having an invention commercialized a couple of years sooner is likely not worth an additional decade of monopoly pricing. ${ }^{225}$ Furthermore, this concern can be ameliorated by allowing the university (potentially in concert with a potential exclusive licensee) to set due diligence milestones for commercialization that better assure heightened quality. Alternatively, when commercialization is readily quantifiable, bidders might compete on how much commercialization they will do for a certain amount of exclusivity. ${ }^{226}$ In circumstances where the potential differential in commercialization quality looms especially large, grant agreements might waive the market test duty. But even when quality is important, follow-on licensees under our proposal will have free access to practice the invention and will be firstmovers with regard to commercialization improvements.

We think the most concerning potential gaming of our market test system would be an incumbent firm that seeks to prevent market entry of a competing technology. This problem seems most likely to appear in the pharmaceutical context, given the high stakes. ${ }^{227}$ For example, if a firm has a monopoly over treatment for a certain disease and seeks to prevent a new drug from competing with its existing product, the firm might agree to commercialize the new drug for free (or for the lowest number of years of exclusivity in an auction) and then fail to conduct clinical trials in good faith. This situation could also occur outside the pharmaceutical context whenever an incumbent firm seeks to prevent market entry of a competing technology.

225 See Michael Abramowicz \& John F. Duffy, The Inducement Standard of Patentability, 120 YALE L.J. 1590, 1627 (2011) [hereinafter Abramowicz \& Duffy, The Inducement Standard of Patentability] (explaining that patents should not be granted if they accelerate invention by a period for which "the social benefits of the invention's existing for that time period are equal to [or less than] the social costs of patent protection for the patent term minus that period").

226 Bidders could also compete on some combination of exclusivity and commercialization. The tradeoffs are similar to those discussed in the literature on price versus quantities. See generally Martin L. Weitzman, Prices vs. Quantities, 41 REV. ECON. STUD. 477 (1974).

227 See supra note 28 and accompanying text. For examples of the vigor with which brand-name pharmaceutical companies will protect their monopolies, see FTC v. Actavis, Inc., 133 S. Ct. 2223, 2229 (2013), in which the brand-name company paid over $\$ 200$ million to generic firms that were challenging its patent to get them to drop the suit and stay off the market, and Caraco Pharm. Labs., Ltd. v. Novo Nordisk A/S, 132 S. Ct. 1670, 1679-82 (2012), in which the brandname company incorrectly changed its patent information filed with the Food and Drug Administration (claiming that its patent covered a use of its drug that it did not) and then argued that a generic challenger had no means of correcting this filing. 
To deter such behavior, it may be worth having a presumption against licensing Bayh-Dole patents to firms that already market a product that competes with the new invention. Additionally, this kind of bad-faith behavior by incumbent firms may be deterred by antitrust review. Exclusive licenses to medical patents are regarded as acquisitions for purposes of premerger reviews by the Federal Trade Commission. ${ }^{228}$ Some licenses might not meet the notification thresholds; for 2016 , premerger notification is only required for transactions valued at least at $\$ 78.2$ million. 229 Congress could consider decreasing these reporting thresholds for exclusive licenses to Bayh-Dole patents.

To address the opposite problem of too much exclusivity rather than too little, Congress might bar a Bayh-Dole licensee from suing any other firms who commercialize the invention before they do. The economic analysis here is similar to the case for an independent invention defense from patent infringement: if patents are meant to incentivize invention, then they should not be wielded against those who independently created the invention without the inducement of a patent. ${ }^{230}$ Analogously, when the main function of patents is to promote commercialization (as seems likely for most Bayh-Dole patents), then they should not be used against firms that commercialize without the incentive of exclusive rights. In fact, the case for an "earlier commercializer" defense is even stronger than the case for an independent invention defense given that successful commercialization should be publicly visible, leading to fewer evidentiary problems.

Those implementing our market test can experiment with many other options for better aligning universities' incentives with the goal of preventing commercialization gaming by licensees. For example, it may be worthwhile to give technology

228 See 15 U.S.C. $\$ 18 a$ (2012) (specifying that certain asset acquisitions may not be executed unless notification with the Federal Trade Commission is filed and a specified waiting period has expired); 16 C.F.R. $\$ 801.2(\mathrm{~g})(2-3)$ ("The transfer of patent rights covered by this paragraph constitutes an asset acquisition ... if all commercially significant rights to a patent . . . for any therapeutic area (or specific indication within a therapeutic area) are transferred to another entity."). 229 Federal Trade Commission, Revised Jurisdictional Thresholds for Section 7A of the Clayton Act, 81 Fed. Reg. 4299, 4300 (Jan. 26, 2016).

230 See Samson Vermont, Independent Invention as a Defense to Patent Infringement, $105 \mathrm{MiCH}$. L. REv. 475, 493-99 (2006); see also Mark A. Lemley, Should Patent Infringement Require Proof of Copying?, $105 \mathrm{MiCH}$. L. REV. 1525, 1527-32 (2007) (explaining the merits of Vermont's proposal); Abramowicz \& Duffy, The Inducement Standard of Patentability, supra note 225, at 1677 (arguing that independent invention should weigh heavily in favor of finding a patent to be obvious). 
transfer offices an incentive to track utilization of university inventions outside the patent system. As noted above, academic researchers often seem strongly motivated by attribution and the corresponding increase in credibility, ${ }^{231}$ so they may be highly motivated to cooperate if they receive credit for certified instances of commercialization of their inventions. It might also be worth offering a prize of additional research funds to universities that are the most successful at achieving widespread dissemination of their inventions or to allow universities to charge nominal licensee fees potentially up to some modest overall revenue cap to their nonexclusive licensees. Universities can be enlisted in policing commercialization without maintaining their current monopolist status. ${ }^{232}$

Finally, policymakers and universities might consider whether third-party firms might be more effective at any stages of this process. Private firms that aggregate patents from multiple universities might be more effective than individual technology transfer offices at conducting the market test we describe. And third-party auditors could be used to certify that inventions actually are available to the public on reasonable terms, or to help quantify technology transfer outside the patent system for the commercialization prize suggested above. ${ }^{233}$

We do not claim to have the solution to all of the logistical problems that might arise with implementation of the market test, which is why we think it is important to begin by testing the market test at a few universities. Undoubtedly, agency regulations informed by experience would need to evolve. But the potential gains from reducing the needless output restrictions worked by many Bayh-Dole patents makes the case for trying to harness the willingness of market actors to bring inventions to the market on a more competitive basis.

231 See supra note 60 and accompanying text. For a more general discussion of how attribution is important to creators and how IP law might respond, see Jeanne C. Fromer, Expressive Incentives in Intellectual Property, 98 VA. L. REV. 1745, 1790-98 (2012).

232 This carrot of a prize for evidence of successful dissemination might, as noted above, be tied to the stick of decreased grant funding for universities that seem to be avoiding implementation, whether strategically or lazily. See generally Ian Ayres \& Amy Kapczynski, Innovation Sticks: The Limited Case for Penalizing Failures To Innovate, 82 U. CHI. L. REv. 1781 (2015) (discussing the use of both carrots and sticks as innovation incentives).

233 Cf. Michael Abramowicz \& John F. Duffy, Ending the Patenting Monopoly, 157 U. PA. L. REV. 1541, 1582 (2009) (explaining how to provide appropriate incentives for private patent examination firms, such as by conducting random government audits). 


\section{CONCLUSION}

This Article is our attempt to "mend, not end" the Bayh-Dole Act. In passing this statute, Congress was right that there are many contexts where socially valuable inventions would be "gathering dust" without the ability to grant initial commercializers exclusive licenses. No pharmaceutical producers will spend tens or hundreds of millions of dollars on human subject testing without such protection. But many other inventions do not need a promise of exclusivity to be brought to market. Stanford's widely licensed patents on early recombinant DNA technology are an especially vivid example, where scores of licensees were willing to make the technology commercially applicable, but these patents are not outliers. ${ }^{234}$

The problem is that for many government-funded inventions, lawmakers lack the requisite information and expertise to determine whether exclusive patent grants are necessary to incentivize commercialization. This problem is endemic to many aspects of patent law. As a theoretical matter, it might be better to have different patent lengths for different industries, ${ }^{235}$ but informationally constrained lawmakers often need to regulate with blunt, one-size-fits-all rules. ${ }^{236}$

The question of whether Bayh-Dole patents can be commercialized without exclusivity, we argue, is one instance in which this informational gap can be filled. Universities can simply find out whether any firms are willing to commercialize the invention in exchange for a free nonexclusive license or for an exclusive license for less than the full patent term. Our proposed market test auction leverages competition among potential commercializers to tell funding agencies how much exclusivity is really needed to achieve practical application of an invention.

We hope that even the readers who are most skeptical of an auction mechanism will at least agree on this: if commercialization theory is the justification for university patents, then those patents that are nonexclusively licensed in ways that do not

234 See supra notes 10-16 and accompanying text.

235 Many patent scholars have proposed such a regime. See, e.g., Benjamin N. Roin, The Case for Tailoring Patent Awards Based on Time-to-Market, 61 UCLA L. REV. 672 (2014). Dan Burk and Mark Lemley have argued that courts already provide significant industry-specific tailoring. Dan L. Burk \& Mark A. Lemley, Policy Levers in Patent Law, 89 VA. L. REV. 1575 (2003).

236 When the government does have sufficient information to determine the optimal reward for each invention, it is generally better to rely on grants or prizes. See Hemel \& Ouellette, Beyond the Patent-Prizes Debate, supra note 32 , at 327-32. 
constrain quantity should not have been sought at all. The licensing revenues and attendant deadweight losses associated with such patents were unnecessary because these inventions were commercialized without an exclusive promise. ${ }^{237}$ If there turn out to be few inventions that firms are willing to commit to commercialize for less than full exclusive patent rights, then our proposal would change little from the status quo aside from the administrative costs of experimenting with some of these auctions-such inventions could be exclusively licensed as usual. But if our market test is successful at finding inventions for which exclusive rights are not needed for commercialization, then it could lead to significant savings for the public and increased access to university technologies.

237 If there are other justifications for these patents, then Bayh-Dole theory and practice must be modified to encompass these. And whatever the best publicspirited justification for Bayh-Dole patents is, policymakers should consider whether alternative legal rules-such as requiring a market test-would better align university incentives with the public interest. 
APPENDIX

As in the text, we continue to assume annual demand for invention,

$$
P=a-b Q,
$$

and we assume that the costs of commercialization are a fixed $C_{l}$. The monopoly price for the good, set where marginal cost $(=0)=$ marginal revenue, will be $a / 2$, and the monopoly quantity will be $a / 2 b$ so that the monopoly revenue will be $\left(a^{2} / 4 b\right)$.

\section{Non-Consumer Reservation Bids}

The reservation bid of a non-consumer bidder with given $C_{i}$ will be the bid that produces zero profits. So if bidding over patent duration, the reservation bid $Y$ will be:

$$
C_{i}=\frac{a^{2}}{4 b} * \frac{1}{r} *\left[1-(1+r)^{-Y}\right],
$$

where the bracketed term represents the annuitization factor of receiving the monopoly revenue for $Y$ years. Note possibility that the reservation bid might be greater than the standard patent length of twenty years if more years of monopoly profit are necessary to produce sufficient incentives to commercialize.

The reservation price equation can be solved for $Y$ :

$$
Y=-\frac{\log \left(1-r C_{i} /\left(\frac{a^{2}}{4 b}\right)\right)}{\log (1+r)}
$$

In this model, bidding over price is equivalent to bidding over the periodic revenue. If bidding is over the price $P$, then the reservation bid can be derived from the equation setting the commercialization cost equal to the present value of earning the profits associated with bid $P$ for twenty years:

$$
C_{i}=P *\left(\frac{a-P}{b}\right) * \frac{1}{r} *\left(1-(1+r)^{-20}\right) .
$$

This equation, which is quadratic in $P$, can be solved for $P$.

$$
P=\frac{1}{2} *\left[a-\left(a^{2}-\frac{4 C_{i} b}{D}\right)^{\frac{1}{2}}\right] .
$$


While there are two roots that solve the reservation price equation (Equation Al) (one corresponding to a price above and one corresponding to a price below the profit-maximizing monopoly price), competition among the bidders would drive a bidder to the smaller root listed above in Equation A2.

\section{Monopsonist Reservation Bids}

From Equation 3 in the text, we know that:

$$
C S_{B} * A(20)=C S_{C} * A(20)-C_{i},
$$

where $C S_{B}$ and $C S_{C}$ are, respectively, the consumer surplus for a particular bid, $B$, and for the competitive equilibrium, and as before $A(20)$ is the twenty year annuitization rate and $C_{1}$ is the monopsonist's commercialization costs. It is also straightforward to derive that:

$$
\begin{gathered}
C S_{B}=\frac{1}{2}(a-B) * Q(B), \quad P_{C}=0, \quad Q_{C}=\frac{a}{b}, \\
Q(B)=\frac{a-B}{b}, \\
C S_{C}=\frac{1}{2}(a-0) *\left(\frac{a}{b}\right)=\frac{a^{2}}{2 b} .
\end{gathered}
$$

Plugging into Equation $\mathrm{A} 3$, the reservation price can be derived from:

$$
A(20) *\left(\frac{a^{2}}{2 b}-\frac{(a-B)^{2}}{2 b}\right)=C_{i},
$$

which again is quadratic in $B$. The smaller, relevant root can be derived as:

$$
B=\frac{a * A(20)-\sqrt{A(20)\left(a^{2} A(20)-2 b C_{i}\right)}}{A(20)} .
$$

From Equation 5 in the text, we know:

$$
s_{i} * A(20) * C S_{B}=A(20) *\left(1-s_{i}\right) * R_{B}+s_{i} * A(20) * C S_{C}-C_{i},
$$

which can be rewritten as:

$s * A(20) * \frac{(a-B)^{2}}{2 b}=A(20) *(1-s) * \frac{B(a-B)}{b}+s * A(20) * \frac{a^{2}}{2 b}-C_{i}$. 
This is again quadratic in $B$, and the smaller relevant root can be solved to be:

$$
B=\frac{a * A(20)-\sqrt{A(20)\left(a^{2} A(20)+2 s b C_{t}-4 b C_{l}\right)}}{(2-s) * A(20)} .
$$

